\title{
Manganese acquisition and homeostasis at the host-pathogen interface
}

\author{
John P. Lisher ${ }^{1}$ and David P. Giedroc ${ }^{1,2 *}$ \\ ${ }^{1}$ Graduate Program in Biochemistry, Indiana University, Bloomington, IN, USA \\ 2 Department of Chemistry, Indiana University, Bloomington, IN, USA
}

\author{
Edited by: \\ Mathieu F. Cellier, Institut National \\ de la Recherche Scientifique, \\ Canada \\ Reviewed by: \\ Eric P. Skaar, Vanderbilt University, \\ USA \\ John Helmann, Cornell University, \\ USA \\ Adam Linstedt, Carnegie Mellon \\ University, USA \\ *Correspondence: \\ David P. Giedroc, Department of \\ Chemistry, Indiana University, 800 \\ E. Kirkwood Avenue, Bloomington, \\ IN 47405-7102, USA \\ e-mail: giedroc@indiana.edu
}

Pathogenic bacteria acquire transition metals for cell viability and persistence of infection in competition with host nutritional defenses. The human host employs a variety of mechanisms to stress the invading pathogen with both cytotoxic metal ions and oxidative and nitrosative insults while withholding essential transition metals from the bacterium. For example, the S100 family protein calprotectin (CP) found in neutrophils is a calcium-activated chelator of extracellular $\mathrm{Mn}$ and $\mathrm{Zn}$ and is found in tissue abscesses at sites of infection by Staphylococcus aureus. In an adaptive response, bacteria have evolved systems to acquire the metals in the face of this competition while effluxing excess or toxic metals to maintain a bioavailability of transition metals that is consistent with a particular inorganic "fingerprint" under the prevailing conditions. This review highlights recent biological, chemical and structural studies focused on manganese $(\mathrm{Mn})$ acquisition and homeostasis and connects this process to oxidative stress resistance and iron (Fe) availability that operates at the human host-pathogen interface.

Keywords: manganese, ATP-binding cassette, metal transport, homeostasis, nutritional immunity, iron

\section{INTRODUCTION}

The most abundant transition metals in humans are iron $(\mathrm{Fe})$ and zinc (Zn) (for reviews, see Maret, 2010; Hood and Skaar, 2012) and it is generally accepted that a clinical deficiency in host levels of either metal increases the incidence of infectious disease and mortality (Haider and Bhutta, 2009; Kumar and Choudhry, 2010; Lassi et al., 2010). These deficiencies reduce the ability of the host to utilize these metals to restrict bacterial growth. In the case of Fe, many peroxide- and nitrous oxide-generating enzymes are iron-dependent, and a limitation of iron would compromise this aspect of innate immunity against bacterial pathogens (Kumar and Choudhry, 2010). Zinc deficiency compromises function of the human immune system (Kitamura et al., 2006) and the ability of the host to induce zinc-mediated cellular toxicity as a means to control bacterial infections (for a review, see Stafford et al., 2013); as a result, this condition is associated with an increased incidence of serious infectious disease (Lassi et al., 2010). In contrast, although manganese (Mn) overload is connected to neurological dysfunction (for a review, see Rivera-Mancía et al., 2011) there is not as yet, strong support for the idea that host Mn(II) sufficiency is in any way coupled to the incidence or severity of infectious disease.

There is now, however, emerging evidence that the invading microbe utilizes Mn as a key micronutrient to resist the effects of host-mediated oxidative stress and thus plays a significant role in adaptation of pathogenic bacteria to the human host. This review summarizes recent work in the area of "Mn-centric" nutritional immunity (Weinberg, 1975) placed in the context of the inorganic physiology of the cell and the "fight over metals" implied by recent studies of Mn speciation and chemistries of low molecular weight (LMW) Mn complexes (McNaughton et al., 2010; Barnese et al., 2012; Sharma et al., 2013), and the structures and metal binding affinities of the bacterial high affinity import systems for Mn relative to the extracellular antibacterial protein calprotectin (Corbin et al., 2008; Damo et al., 2013; Hayden et al., 2013). Calprotectin possesses functional properties consistent with that of an extracellular Mn chelator that withholds this metal from the invading pathogen (Kehl-Fie et al., 2013) and is thus formally analogous to siderochalins that capture $\mathrm{Fe}$-siderophores synthesized by the pathogen itself (Flo et al., 2004; Sia et al., 2013). Finally, recent insights into the coordinate regulation and crosstalk that govern intracellular Mn vs. Fe and Mn vs. Zn bioavailability will also be discussed.

\section{INORGANIC CHEMISTRY OF THE CELL: TOTAL METAL AND CELLULAR METAL SPECIATION}

Six first-row $3 d$-block elements extending from manganese to zinc are essential micronutrients that function as inorganic cofactors in up to $25 \%$ of all proteins in cells (Figure 1A) (Waldron and Robinson, 2009). Mn, Fe, $\mathrm{Cu}$ and $\mathrm{Zn}$ are ubiquitous in biology (Maret, 2010) while cobalt (Co) and nickel (Ni) play more specialized roles in methyl transfer chemistry (Gherasim et al., 2013) and as a cofactor for a limited number of $\mathrm{Ni}(\mathrm{II})$-containing metalloenzymes (Kaluarachchi et al., 2010), respectively. $\mathrm{Zn}$ is unique among these metals in that it is redox-inert and thus stable in the $2+$ oxidation state. As such, Zn functions as nature's principal Lewis acid catalyst, where it activates a substrate for catalysis. $\mathrm{Zn}$ is a cofactor in a wide range of hydrolytic enzymes, constitutes the largest fraction of metalloproteins in the cell (Maret, 2001) and stabilizes protein structure in the reducing environment of the cytoplasm. Fe readily accesses $\mathrm{Fe}$ (II) and $\mathrm{Fe}$ (III) oxidation states in $2 \mathrm{Fe}-2 \mathrm{~S}$ and $4 \mathrm{Fe}-4 \mathrm{~S}$ iron-sulfur proteins involved in electron transfer, with higher valence Fe(IV)-oxo species in both heme and non-heme Fe-containing enzymes responsible 


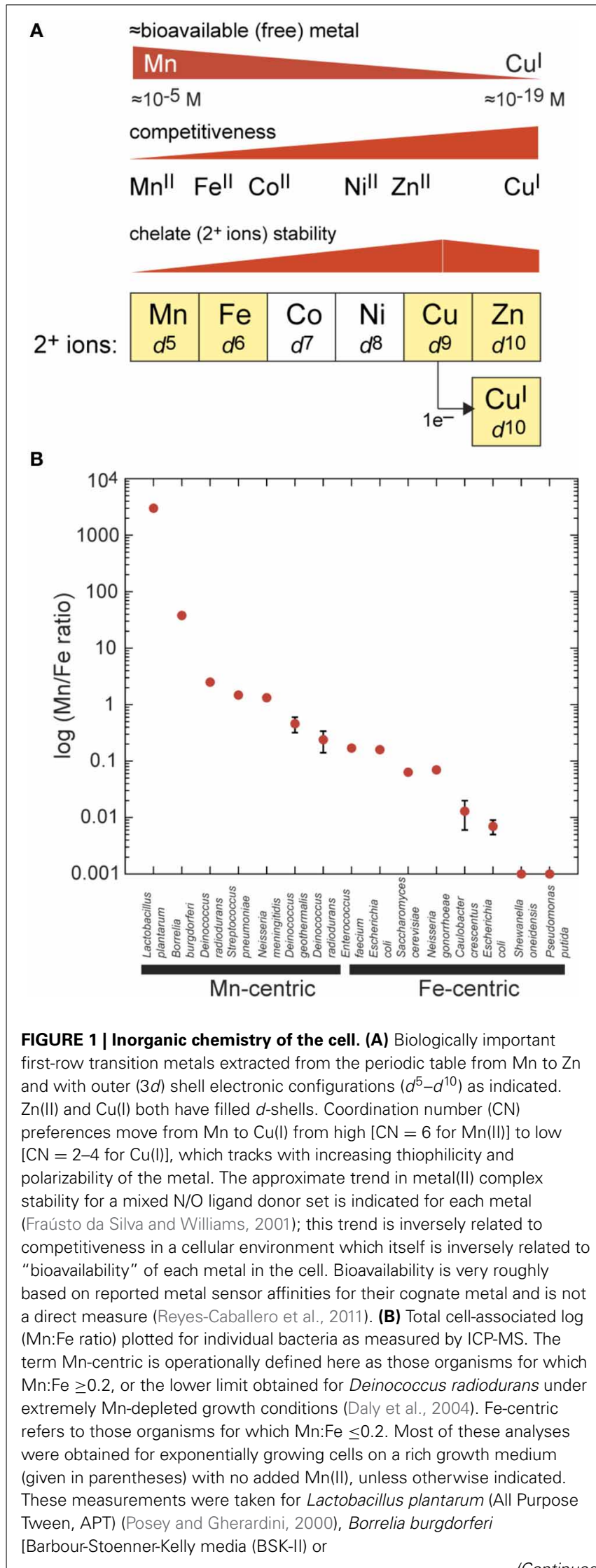

(Continued)

\section{FIGURE 1 | Continued}

Modified serum-free media with Exyte (SF-E)] (Posey and Gherardini, 2000), Deinococcus radiodurans (Defined Minimal media $+2.5 \mu \mathrm{M} \mathrm{Mn)} \mathrm{(Daly}$ et al., 2004), Streptococcus pneumoniae (Brain Heart Infusion, BHI) (Jacobsen et al., 2011), Neisseria meningitidis (Gonococcal Broth, GCB) (Veyrier et al., 2011), Deinococcus geothermalis (Tryptone Glucose Yeast extract media, TGY) (Daly et al., 2004), Deinococcus radiodurans (TGY) (Daly et al., 2004), Enterococcus faecium (TGY) (Daly et al., 2004), Escherichia coli (Luria Broth, LB) (Outten and O'Halloran, 2001), Saccharomyces cerevisiae (Yeast extract Peptone Dextrose media, YPD) (Rosenfeld and Culotta, 2012), Neisseria gonorrhoeae (GCB) (Veyrier et al., 2011), Caulobacter crescentus (Peptone Yeast Extract media, PYE) (Hughes et al., 2013), Escherichia coli (TGY) (Daly et al., 2004), Shewanella oneidensis (TGY; Mn/Fe $0.0005 \pm 0.00004$ ) (Daly et al., 2004), and Pseudomonas putida (TGY; <0.001) (Daly et al., 2004).

for significant oxygen insertion and oxygen activation chemistry (Andrews et al., 2003). Fe is also the obligate cofactor for Fesuperoxide dismutase (Fe-SOD) and nearly all ribonucleotide reductases, although more recently, di-Mn-containing variants have been discovered and characterized (for a review, see Cotruvo and Stubbe, 2012).

$\mathrm{Mn}$, like $\mathrm{Zn}$, is a Lewis acid cofactor in a number of hydrolytic enzymes, e.g., protein phosphatases, and in key enzymes of intermediary metabolism, but is redox-active [to $\mathrm{Mn}$ (III), $\mathrm{Mn}$ (IV) and $\mathrm{Mn}(\mathrm{V})]$ and is most strongly linked to oxidative stress resistance mediated by Mn superoxide dismutase (Mn-SOD) (Culotta et al., 2006) and non-heme di-Mn catalases (Whittaker, 2012). As discussed below, simple small molecule $\mathrm{Mn}(\mathrm{II})$-complexes, unique to $\mathrm{Mn}(\mathrm{II})$, may have substantial antioxidant activity inside cells (Barnese et al., 2008, 2012). Finally, the bacterial requirement for intracellular $\mathrm{Cu}$, outside of the photosynthetic bacteria, is generally accepted to be low (Waldron et al., 2009); as a result, there is emerging evidence that the human host harnesses the cytotoxic power of $\mathrm{Cu}$ to kill invading bacterial pathogens (White et al., 2009; Rowland and Niederweis, 2012; Samanovic et al., 2012); this need not, however, be the case for all microbial pathogens (Raja et al., 2013).

The inorganic "fingerprint" of unstressed cells is defined as the total concentration of all cell-associated metals summed over all cellular fractions (membrane, cytoplasm, periplasm, etc.). This is generally expressed in nmol or ng of each metal per mg total protein and is readily measured by inductively coupled plasma mass spectrometry (ICP-MS) of acid-solubilized cells. A remarkable aspect of the inorganic fingerprint relevant to this discussion is the fact that the total $\mathrm{Mn}$ :Fe ratio varies by over seven orders of magnitude when various single-celled organisms are compared with one another (Figure 1B). If Escherichia coli is taken as a typical bacterium, then $\mathrm{Zn}$ is as abundant as $\mathrm{Fe}$, with $\mathrm{Mn}$ and $\mathrm{Cu}$ present at $\approx 10$-fold lower concentration, and $\mathrm{Ni}$ and Co about 10-50 fold lower still (Outten and O'Halloran, 2001; Maret, 2010), giving a $\mathrm{Mn}: \mathrm{Fe}$ ratio of $\approx 0.1$. This fingerprint tends to characterize "Fe-centric" bacteria, like E. coli and the yeast Saccharomyces cerevisiae (Outten and O'Halloran, 2001; Rosenfeld and Culotta, 2012) with some Fe-centric species accumulating only vanishingly small amounts of $\mathrm{Mn}$ ( Mn:Fe ratio $\leq 0.001$ ) (Figure 1B) (Daly et al., 2004). On the other hand, for some Gram-positive bacteria, total cell-associated Mn levels are 
on par with that of $\mathrm{Zn}$, with Fe levels correspondingly lower, resulting in a $\mathrm{Mn}$ :Fe ratio of $\geq 1$ for these $\mathrm{Mn}$-centric organisms (Figure 1B) (Daly et al., 2004; Jacobsen et al., 2011; Veyrier et al., 2011). These bacteria include the lactic acid bacteria Streptococcus pneumoniae and Lactobacillus plantarum, the pathogen Neisseria meningitidis, and the UV-resistant Deinococcus radiodurans. In Deinococcus radiodurans, $\mathrm{Mn}$ is known to play a direct role in protecting this organism from the effects of extreme $\gamma$-radiation (Daly et al., 2004). As a general rule, lactic acid bacteria tend to have less in the way of an intracellular Fe requirement relative to $E$. coli, and this may be a consequence of the unusual lifestyle of these organisms which lack a respiratory chain and yet generate millimolar hydrogen peroxide $\left(\mathrm{H}_{2} \mathrm{O}_{2}\right)$ when grown in the presence of oxygen (Archibald and Fridovich, 1981b; Ramos-Montañez et al., 2010). This would play havoc with an Fe-centric bacterium and in fact is used by lactobacilli to kill other bacteria in the microbial community (see Figure 2 below).

It is important to emphasize that the total metal content of an organism does not dictate the relative concentrations of free metal, which we define here as the fraction of total metal that is rapidly exchangeable with LMW chelates or cellular metabolites and is thus bioavailable (Figure 1A). This bioavailable metal tends to track with the left-to-right arrangement of the $d$-block elements in the periodic table, which is inversely related to metal competitiveness within a cellular environment. Metal competitiveness, in turn, is roughly governed by the intrinsic chelate stability, which provides a measure of the equilibrium ability of one metal to displace another metal from an enzyme active site, for example (Fraústo da Silva and Williams, 2001) (Figure 1A). Both $\mathrm{Zn}(\mathrm{II})$ and $\mathrm{Cu}(\mathrm{I})$ are highly competitive $d^{10}$ metals and thus will outcompete all other divalent transition metals in the first row, in particular $\mathrm{Mn}$ (II) and $\mathrm{Fe}(\mathrm{II})$, if left unregulated (for reviews, see Waldron and Robinson, 2009; Reyes-Caballero et al., 2011). In short, there must be a cellular overcapacity to chelate $\mathrm{Zn}$ (II) in order to keep this highly competitive metal in check (Outten and O'Halloran, 2001) (Figure 1A). In contrast, for Mn(II) (McNaughton et al., 2010; Sharma et al., 2013) and perhaps $\mathrm{Fe}$ (II) in E. coli (Imlay, 2008) a significant fraction of the total cell-associated metal is found in rapid equilibrium with a chelatable pool of LMW metabolite-metal complexes, e.g., amino acids, nucleosides, nucleotides, orthophosphate, citrate, and carbonate. This has significant implications for $\mathrm{Mn}$ (II) and microbial pathogenesis, as discussed below.

\section{TRANSITION METAL HOMEOSTASIS AND THE FIGHT OVER METALS}

The cellular bioavailability of transition metals is governed by continuous cycles of adaptation and recovery to changes in extracellular metal availability, e.g., that which might occur along an infection axis. This process is termed transition metal homeostasis. Metal homeostasis systems maintain both total and bioavailable metal concentrations to maximize cell viability under the prevailing extracellular milieu. This process is orchestrated by a panel of metal sensor proteins that regulate the transcription of genes encoding metal uptake, metal efflux and metal sequestration proteins. Metal sensor proteins are typically repressors whose DNA operator-promoter binding or transcription activation activity is reversibly modulated by the binding of one or more cognate (-like) metal ions to the exclusion of all others (Giedroc and Arunkumar, 2007; Ma et al., 2009). This regulatory process has a tremendous impact on the survival and pathogenesis of microbial pathogens (Andreini et al., 2008; Botella et al., 2012). For example, $\mathrm{Cu}(\mathrm{I})$ and $\mathrm{Zn}(\mathrm{II})$ compete with native metals leading to mismetallation of metalloenzymes with more weakly bound metals and loss of function (Aguirre and Culotta, 2012; Botella et al., 2012; Cotruvo and Stubbe, 2012), while ROS and Fe cause deleterious reactions leading to oxidative damage of proteins, DNA and lipids (Imlay, 2013) (see Figure 2; discussed more fully below).

For bacterial pathogens, proper metallation of critical proteins also competes against host defenses that have evolved to limit or sequester these required micronutrients to quell a bacterial infection, thus creating a "fight over metals" (for a review, see Hood and Skaar, 2012). Furthermore, this fight is intermingled with ongoing global stress mediated by reactive oxygen species (ROS) (Imlay, 2013), reactive chlorine species (HOCl) (Gray et al., 2013) and/or reactive nitrogen species (RNS) (Stern et al., 2013) to which the pathogen must adapt and ultimately exploit (Hoffmann et al., 2006). The ability of the host immune system to sequester transition metals is an important aspect of nutritional immunity (Kehl-Fie and Skaar, 2010). Although long recognized for Fe limitation (Weinberg, 1974, 1975; Forbes and Gros, 2001; Flo et al., 2004; Skaar, 2010; Hammer and Skaar, 2012), it is now established that both $\mathrm{Zn}$ and Mn availability are actively limited by the host as well, through the extracellular action of calprotectin (CP) (Corbin et al., 2008) and perhaps other molecules. Indeed, the host strategy of limiting $\mathrm{Mn}$, in particular, results in sensitization to oxidative stress (Anjem et al., 2009; Ogunniyi et al., 2010; Kehl-Fie et al., 2011) which limits the ability of Mn(II) to function as an antioxidant as discussed below.

\section{MANGANESE AS AN ANTIOXIDANT MICRONUTRIENT}

Manganese as a micronutrient is critical to the viability and virulence of many Gram-positive and Gram-negative bacterial pathogens (Tseng et al., 2001; Johnston et al., 2004; Ogunniyi et al., 2010; Kehl-Fie et al., 2011; Wichgers Schreur et al., 2011; Perry et al., 2012). In these bacteria, deletion of either the manganese import system(s) or the associated $\mathrm{Mn}$ (II)-specific metal sensor protein compromises virulence and/or viability often through sensitizing the bacteria to various ROS, e.g., superoxide anion radical (denoted here as $\mathrm{O}_{2}{ }^{-}$) or hydrogen peroxide $\left(\mathrm{H}_{2} \mathrm{O}_{2}\right)$ (Johnston et al., 2006; Abrantes et al., 2013) (Figure 2). Major consequences of $\mathrm{O}_{2}{ }^{-}$and $\mathrm{H}_{2} \mathrm{O}_{2}$ toxicity in cells is the autocatalytic production of the highly damaging hydroxyl radi$\mathrm{cal}, \mathrm{OH} \bullet$, via the Fenton reaction from these partially reduced forms of $\mathrm{O}_{2}$, and the oxidative attack and dissociation of solventexposed $\mathrm{Fe}(\mathrm{II})$ atoms from enzymes harboring mononuclear $\mathrm{Fe}$ and $4 \mathrm{Fe}-4 \mathrm{~S}$ cluster cofactors (Figure 2). Here, a solvent-exposed $\mathrm{Fe}(\mathrm{II})$ atom will allow for direct coordination of $\mathrm{H}_{2} \mathrm{O}_{2}$ leading to a local generation of $\mathrm{OH} \bullet$ and protein oxidation and $\mathrm{Fe}$ (III) dissociation, essentially analogous to that which occurs in the peroxide sensor Fe-PerR (Lee and Helmann, 2006) (Figure 3). As such, all bacteria encode regulatory strategies to quickly respond to various ROS. In E. coli, low $(\mu \mathrm{M}) \mathrm{H}_{2} \mathrm{O}_{2}$ induces the OxyR regulon 


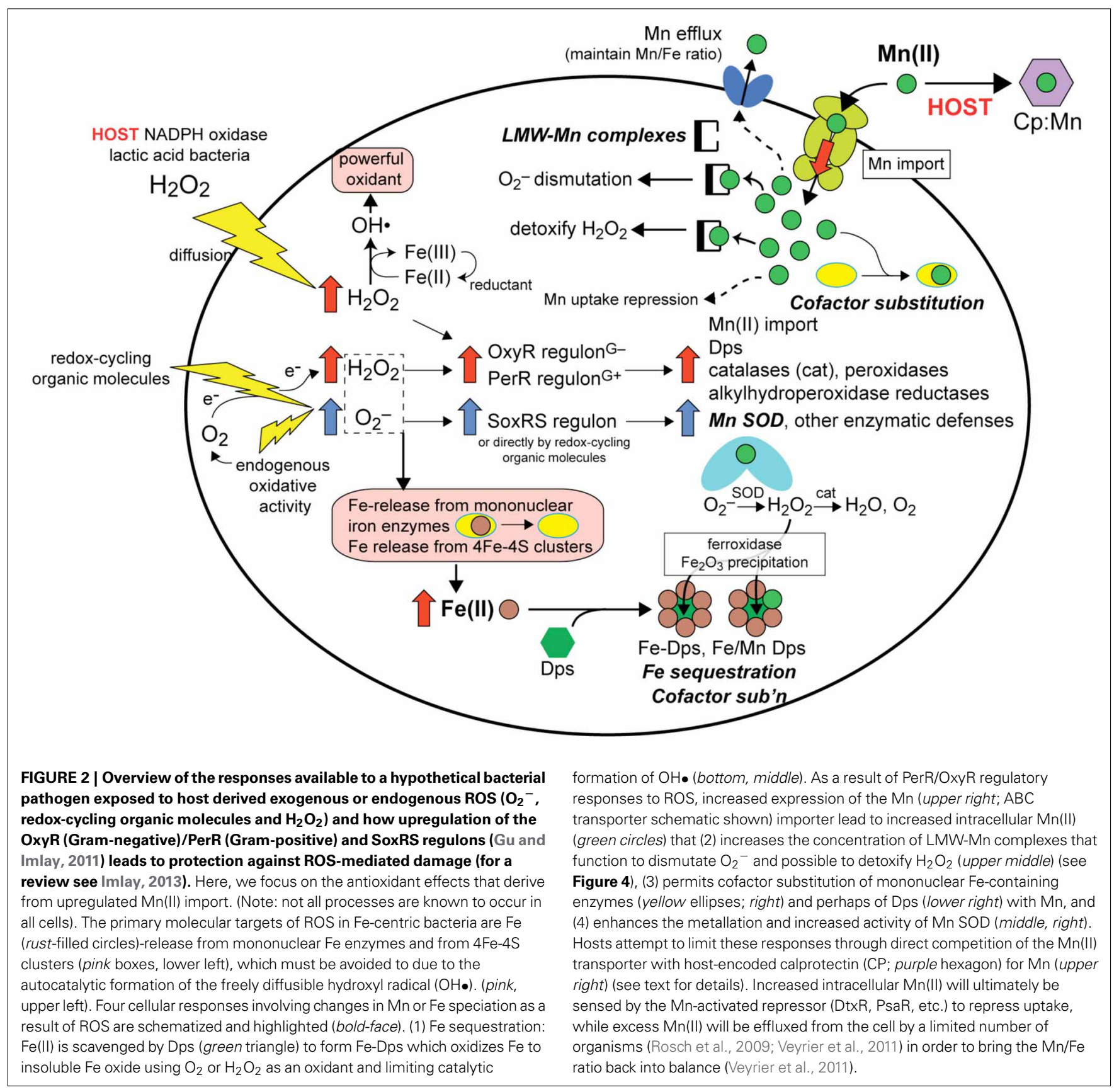

which includes genes encoding a manganese import pump MntH and the DNA binding iron-scavenging protein Dps (Zheng et al., 2001), as well as catalases and peroxidases capable of reducing ROS or organic peroxides (Figure 3). In Gram-positive bacteria, PerR carries out essentially the same regulatory role as OxyR. Redox-cycling organic molecules (Gu and Imlay, 2011) and perhaps $\mathrm{O}_{2}{ }^{-}$itself induce the SoxRS regulon, a major component of which is Mn-superoxide dismutase (SOD).

As a result of ROS stress, four major cellular adaptations result that collectively limit pro-oxidant Fe availability and upregulate Mn import to harness the antioxidant properties of Mn(II). First, increased $\mathrm{Mn}(\mathrm{II})$ availability allows for increased metallation of Mn-SOD which efficiently catalyzes the dismutation of the superoxide anion radical to $\mathrm{H}_{2} \mathrm{O}_{2}$ and $\mathrm{O}_{2}$, the former of which is cleared by catalase and related peroxidases which are also induced under these conditions (May and Dennis, 1989; Wintjens et al., 2004) (Figure 2). However, as early as 1981, a series of studies established that LMW manganese-metabolite complexes from extracts of Lactobacillius plantarum (see Figure 1B) were capable of scavenging superoxide from solution (Archibald and Fridovich, 1981a,b) (Figure 2). A number of diverse bacterial species (Inaoka et al., 1999; Tseng et al., 2001; Al-Maghrebi et al., 2002; Daly et al., 2010; Kehl-Fie et al., 2011) and the baker's yeast Saccharomyces cerevisiae (Chang and Kosman, 1989; McNaughton 
A Proposed noncatalytic mechanism:

$$
\begin{aligned}
& \mathrm{Mn}^{2+}-\mathrm{L}+\mathrm{O}_{2}^{-} \underset{k_{-1}}{\stackrel{k_{1}}{\rightleftarrows}} \mathrm{MnOO}^{1+}+\mathrm{L} \\
& \mathrm{MnOO}^{1+}+\mathrm{L} \underset{\mathrm{H}^{+}}{\stackrel{k_{2}}{\longrightarrow}} \mathrm{Mn}^{3+}-\mathrm{L}+\mathrm{H}_{2} \mathrm{O}_{2}
\end{aligned}
$$

B Proposed catalytic mechanism:

$$
\begin{gathered}
\mathrm{Mn}^{2+}-\mathrm{L}+\mathrm{O}_{2}^{-} \underset{k_{-3}}{\stackrel{k_{3}}{\longrightarrow}} \mathrm{MnOO}^{1+}-\mathrm{L} \\
\mathrm{MnOO}^{1+}-\mathrm{L}+\text { Anion }{ }^{\mathrm{n}-} \underset{\mathrm{k}_{4}}{\stackrel{\mathrm{k}_{-4}}{\longrightarrow}}\left[\mathrm{MnOO}^{1+}-\mathrm{L}-\text { Anion }\right]^{\mathrm{n}-1} \\
\mathrm{MnOO}^{1+}-\mathrm{L}+\mathrm{MnOO}^{1+}-\mathrm{L} \underset{\mathrm{H}^{+}}{\stackrel{k_{5}}{\longrightarrow}} 2 \mathrm{Mn}^{2+}-\mathrm{L}+\mathrm{H}_{2} \mathrm{O}_{2}+\mathrm{O}_{2}
\end{gathered}
$$

C

\begin{tabular}{|l|c|}
\hline Mn complex & Overall Rate \\
\hline $\mathrm{Mn}$ citrate & $2.0 \times 10^{3} \mathrm{~s}^{-1}$ \\
$\mathrm{Mn}-\mathrm{P}_{2} \mathrm{O}_{7}^{2-(a)}$ & $>2 \times 10^{4} \mathrm{~s}^{-1}$ \\
$\mathrm{Mn}-\mathrm{HPO}_{4}{ }^{\mathrm{b}}$ & $8.9 \times 10^{6} \mathrm{M}^{-1} \mathrm{~s}^{-1}$ \\
$\mathrm{Mn}-\mathrm{HCO}_{3}{ }^{1+(\mathrm{b})}$ & $1.5 \times 10^{6} \mathrm{M}^{-1} \mathrm{~s}^{-1}$ \\
\hline
\end{tabular}

D
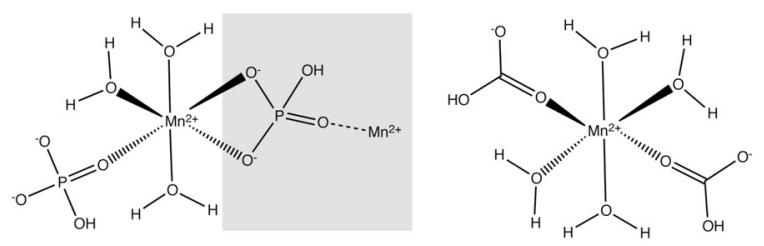

FIGURE 3 | Superoxide disproportionation by LMW-Mn complexes (Barnese et al., 2012). (A) Plausible noncatalytic mechanism of the reaction of $\mathrm{O}_{2}{ }^{-}$with $\left[\mathrm{Mn}(\mathrm{II})-\mathrm{P}_{2} \mathrm{O}_{7}\right]^{2-}$ and $\mathrm{Mn}(\mathrm{II})$-citrate. L, pyrophosphate or citrate. (B) Proposed catalytic mechanism of the reaction of $\mathrm{O}_{2}{ }^{-}$with $\left[\mathrm{Mn}(\mathrm{II})-\mathrm{HPO}_{4}\right]$ and $\left[\mathrm{Mn}(\mathrm{II})-\mathrm{HCO}_{3}\right]^{+}$leading to the catalytic disproportionation of $\mathrm{O}_{2}{ }^{-}$. L, phosphate or carbonate; Anion ${ }^{n-}$ represents an additional bound anion to the form the intermediate. (C) Overall rate constants for the non-catalytic and catalytic disproportionation of $\mathrm{O}_{2}{ }^{-}$, the latter of which incorporates the $\mathrm{MnOO}+$ dependence of $k_{5}$. Rate law simulations reveal that $91 \mu \mathrm{M} \mathrm{MnHPO}_{4}$ (165 $\mu \mathrm{M} \mathrm{Mn(II),} 5 \mathrm{mM}$ phosphate), and $25 \mu \mathrm{M}$ $\mathrm{MnHCO}_{3}^{+}$(formed by $36 \mu \mathrm{M} \mathrm{Mn}(\mathrm{II})$ and $5 \mathrm{mM}$ carbonate) gives rise to a steady-state $\left[\mathrm{O}_{2}{ }^{-}\right](3 \mu \mathrm{M})$ identical to $1 \mu \mathrm{M}$ CuZn-SOD following a $25 \mu \mathrm{M}$ burst of superoxide (Barnese et al., 2012). Thus, intracellular $\mathrm{Mn}(\mathrm{II})$ in the $\approx 100 \mu \mathrm{M}$ range is expected to be sufficient to resist the effects of superoxide stress, as found previously in yeast; these studies also physically document the presence of $\mathrm{MnHPO}_{4}$ species in whole cells (McNaughton et al., 2010). The same may well be true for manganese-centric bacterial pathogens vs. iron-centric E. coli (Aguirre et al., 2013; Sharma et al., 2013) (see Figure 1B). (D) Chemical structures of "layered" $\mathrm{Mn}-\mathrm{HPO}_{4}$, where the gray box encompasses the next layer in the crystal lattice (left) (Krishnamohan Sharma et al., 2003) and a calculated model of frozen neutral $\left[\mathrm{Mn}\left(\mathrm{HCO}_{3}\right)_{2}\right]$ from ENDOR studies (right) (Potapov and Goldfarb, 2008).

et al., 2010; Reddi and Culotta, 2011) are now known to posses this activity as well, although in most cases it is supplemented by SOD enzyme-catalyzed superoxide dismutation, with the prominent exceptions of L. plantarum and Neisseria gonorrhoeae (Tseng et al., 2001).
Simple Mn-phosphate $\left(\mathrm{P}_{\mathrm{i}}\right)$ and $\mathrm{Mn}$-carbonate complexes are efficient catalysts of superoxide disproportionation and the chemical mechanism of this reaction has recently been investigated in detail (Barnese et al., 2008, 2012) (Figure 3). This catalysis occurs at physiologically relevant rates and metabolite concentrations and may well-explain studies that connect oxidative stress resistance to phosphate accumulation and changes in phosphate metabolism (Tseng et al., 2001; Jensen et al., 2003; McNaughton et al., 2010; Rosenfeld et al., 2010; Wu et al., 2010). Additionally, manganese carbonate complexes have been shown to catalyze the decomposition of $\mathrm{H}_{2} \mathrm{O}_{2}$ (Figure 2) suggesting that other small molecule Mn-complexes can potentially function downstream of superoxide, although this reaction has not been thoroughly investigated (Stadtman et al., 1990; Liochev and Fridovich, 2004). Recent findings in $S$. aureus support the presence of manganesedependent, SOD-independent mechanisms to effectively scavenge superoxide (Kehl-Fie et al., 2011).

In addition to the chemical clearance of ROS mediated by LMW-Mn complexes, cofactor substitution (see Figure 2) of $\mathrm{Fe}(\mathrm{II})$ for $\mathrm{Mn}$ (II) in selected mononuclear iron enzymes has recently been proposed to protect these enzymes from redox chemistry at the $\mathrm{Fe}$ active site that accompanies $\mathrm{H}_{2} \mathrm{O}_{2}$ stress (Imlay, 2013) (Figure 2). Indeed, many mononuclear Fe enzymes are reversibly inactivated by $\mathrm{H}_{2} \mathrm{O}_{2}$, and continued exposure leads to irreversible inactivation (Sobota and Imlay, 2011; Anjem and Imlay, 2012). This Fe(II)-for-Mn(II) substitution is facilitated by the generally weak binding (rapid dissociation) of these two metals to enzymes (see Figure 1A) and is predicted to function well in enzymes that employ Fe(II) in Lewis acid catalysis, given the similar coordination preferences of $\mathrm{Fe}(\mathrm{II})$ and $\mathrm{Mn}(\mathrm{II})$; however, this process is projected to fail when the Fe(II) atom needs to undergo a change in oxidation state, given the very different redox potentials of these two metals (Cotruvo and Stubbe, 2012). In any case, Mn is known to protect these enzymes from inactivation in vitro and in vivo where both manganese import and iron sequestration were required for protection (Anjem and Imlay, 2012) (Figure 2). These studies reveal that E. coli is capable of shifting from a metabolism based on $\mathrm{Fe}$ (II) to one based on $\mathrm{Mn}$ (II) in order to protect key enzymes from inactivation by ROS. Another example of this type of cofactor replacement is the iron sequestration protein, Dps, in Kineococcus radiotolerans (Figure 2). Dps is a binuclear Fe-containing ferroxidase that binds Fe and precipitates iron oxide inside of the Dps dodecamer; however, the $K$. radiotolerans enzyme is also active as a mixed metal $\mathrm{Mn}-\mathrm{Fe}$ enzyme, further evidence for the protective role of $\mathrm{Mn}$ (II) via cofactor substitution in the oxidative stress response (Ardini et al., 2013).

Thus, Mn(II) functions as an antioxidant through a combination of enzymatic degradation of oxidants by Mn-SOD and other Mn(II)-containing enzymes, nonenzymatic degradation of oxidants by LMW-Mn complexes, and metalloenzyme cofactor substitution to prevent Fe-induced peroxide chemistry and subsequent enzyme inactivation (Figure 2). The extent to which each process contributes likely varies from organism to organism and will be dependent on the prevailing microenvironment. However, a metabolism capable of utilizing $\mathrm{Mn}$ (II) and not absolutely dependent on Fe may well-represent a general strategy that 
nature has evolved to develop robust viability in the presence of significant or chronic ROS. The causative agent of Lyme disease, Borrelia burgdorferi, which completely lacks an Fe requirement and as a result is characterized by a very high $\mathrm{Mn}: \mathrm{Fe}$ ratio (Figure 1B), may represent an extreme example of this evolutionary adaptation that protects the organism from host-mediated ROS (Posey and Gherardini, 2000; Aguirre et al., 2013).

\section{STRUCTURAL STUDIES OF BACTERIAL MANGANESE IMPORT SYSTEMS}

The ability of a bacterial pathogen to obtain sufficient $\mathrm{Mn}$ (II) is critically important for pathogenesis and as such, Mn(II)dependent metal sensor proteins control the expression of operons that encode additional virulence factors unrelated to the acquisition of $\mathrm{Mn}$ (II) (Gold et al., 2001; Johnston et al., 2006; Rolerson et al., 2006; Hendriksen et al., 2009). This suggests that $\mathrm{Mn}$ (II) limitation may well be a generic signal that poises the invading pathogen to quickly adapt to a wide range of host immune defenses. Unlike the case for Fe siderophores, there is no known LMW, high affinity chelator that is secreted by bacteria to scavenge $\mathrm{Mn}$ from the environment. As a result, the capture and transport of manganese into the cell is facilitated directly by manganese import systems, which include $\mathrm{MntH}$, a NRAMP1 (natural resistance-associated macrophage protein 1)family transporter and the $\mathrm{Mn} / \mathrm{Fe} / \mathrm{Zn}$-specific cluster A-I ABC (ATP-Binding Cassette) transporters (Dintilhac and Calverys, 1997; Papp-Wallace and Maguire, 2006; Berntsson et al., 2010).

Although structural studies of bacterial NRAMP1 Mn/Fetransporters are limited, some molecular-level insights are available from extensive modeling studies for this large family of proteins (Cellier, 2012). Limited structural information is available for intact multisubunit cluster A-I ABC transporters as well, although the crystallographic structures of the distantly related bacterial cobalamin transporter $\mathrm{BtuC}_{2} \mathrm{D}_{2} \mathrm{~F}$ (Locher et al., 2002; Korkhov et al., 2012) and the molybdate transporter $\left(\mathrm{ModB}_{2} \mathrm{C}_{2} \mathrm{~A}\right)$ are known to modest resolution (Hollenstein et al., 2007). Significant structural data are, however, available for component metal-binding subunits of cluster A-I ABC transporters, termed the solute-binding proteins (SBPs) (Figure 4A). These include a number of Mn- and $\mathrm{Zn}$-specific SBPs (Lawrence et al., 1998; Lee et al., 1999, 2002; Banerjee et al., 2003; Rukhman et al., 2005; Chandra et al., 2007; Li and Jogl, 2007; McDevitt et al., 2011; Zheng et al., 2011; Gribenko et al., 2013). It is generally believed that the SBP defines the metal specificity of transport, although precisely how this is accomplished is currently unknown. In addition, $\mathrm{Zn}$ is generally a poor substrate and in some cases, a competitive inhibitor, of Mn-specific ABC transporters (DeWitt et al., 2007) despite forming a very similar coordination complex to that of $\mathrm{Mn}$ (II) (see below).

The first of the cluster A-I SBPs (Berntsson et al., 2010) to be structurally characterized was PsaA from Streptococcus pneumoniae (Lawrence et al., 1998), solved as the $\mathrm{Zn}$ (II)-complex to $2.0 \AA$ resolution, and lacking the $\mathrm{N}$-terminal LXXC motif required to anchor PsaA to the lipid membrane. We use the recently determined structure of $\mathrm{Mn}$ (II)-bound S. aureus $\mathrm{MntC}$ to illustrate the fold of this subfamily of SBPs, described as a "Venus fly trap" containing two homologous mixed $(\beta \alpha)_{4}$ sandwich domains linked via a $\approx 30$ amino acid helix that resembles a backbone brace for this two-domain molecule (Figure 4B). The metal binding site is located in a deep cleft between the two domains of MntC, and metal ligands are contributed by both domains in roughly homologous positions (H50, H123 in the N-terminal domain; E189, D264 in the C-terminal domain). The structure of the apostate of MntC is unknown, but structural studies of ligand-free Treponema TroA (Lee et al., 2002) and the SBP specific for vitamin $\mathrm{B}_{12}$ (BtuF) reveal essentially closed, metal bound-like structures, with BtuF indicative of a slightly more open and conformationally dynamic structure that collapses around the $\mathrm{Co}$ (II)-ligand complex (Karpowich et al., 2003). The Mn(II) in MntC is bound to four protein-derived ligands in what is best described as a pentacoordinate distorted trigonal bipyramidal coordination geometry (Figure 4C) that is completely shielded from solvent (Figure 4D). The structure of the Mn(II)-bound form of PsaA has also recently been solved and compares very favorably with that of Mn-MntC (Figures 4E,F) (McDevitt et al., 2011). While the overall structure is virtually identical with that of $\mathrm{Zn}$ (II)-PsaA complex determined earlier (see Figure 4E for an overlay) (Lawrence et al., 1998), there are subtle differences in the metal coordination site, with the $\mathrm{Zn}$ (II) complex tending toward distorted tetrahedral as a result of monodentate coordination by each of the two carboxylate ligands (E205, D280) (Figure 4F). These trends in metal coordination geometry of $\mathrm{Mn}(\mathrm{II})$ vs. $\mathrm{Zn}$ (II) are consistent with expectations (Dudev and Lim, 2013), although the resolution of the structures precludes a stronger conclusion on this point. It is important to point out that some Zn-specific SBPs, e.g.,E. coli ZnuA, lack the bidentate Asp ligand of Mn-specific SBPs, e.g., D280 in Figure 4F, and recruit a solvent molecule to complete the tetrahedral coordination complex using the other three Mn-SBP ligands (Chandra et al., 2007). This may well have strong implications for metal specificity and the forward rate of cognate or native metal transport across the membrane. A recent paper provides new insights on molecular basis of functional discrimination of cognate $\mathrm{Mn}(\mathrm{II})$ vs. non-cognate $\mathrm{Zn}(\mathrm{II})$ by S. pneumoniae PsaA (Couñago et al., 2013).

The structures of other Mn(II)-specific cluster A-I SBPs have been reported including those from distant bacterial phyla such as cyanobacteria (Rukhman et al., 2005) and the spirochaete Treponema, the causative agent of syphilis (Lee et al., 1999). Each structure shares the same MntC/PsaA fold revealing that the $(\beta \alpha)_{4}$ sandwich two-domain structure is evolutionarily conserved and is utilized for transition metal transport in both Gram-negative and Gram-positive bacteria and in nonpathogenic and pathogenic bacteria alike. Given the ubiquity of these proteins on the "outside" of Gram-positive organisms, they have been targeted for use in commercial vaccines. For example, improved serotype coverage and clearance of Streptococcus pneumoniae has been obtained with a vaccine containing adjuvant-conjugated PsaA, PiuA and PiaA, the latter two of which are involved in $\mathrm{Fe}$-uptake in this organism (Brown et al., 2001; Whaley et al., 2010).

Since $\mathrm{Mn}(\mathrm{II})$ can only enter the cytoplasm efficiently through $\mathrm{Mn}$ (II)-specific transporters, elucidation of the affinity of each for $\mathrm{Mn}(\mathrm{II})$ vs. noncognate $\mathrm{Zn}$ (II) and the rates at which $\mathrm{Mn}(\mathrm{II})$ is transported across the plasma membrane takes on added significance when considered in the context of the discovery of 


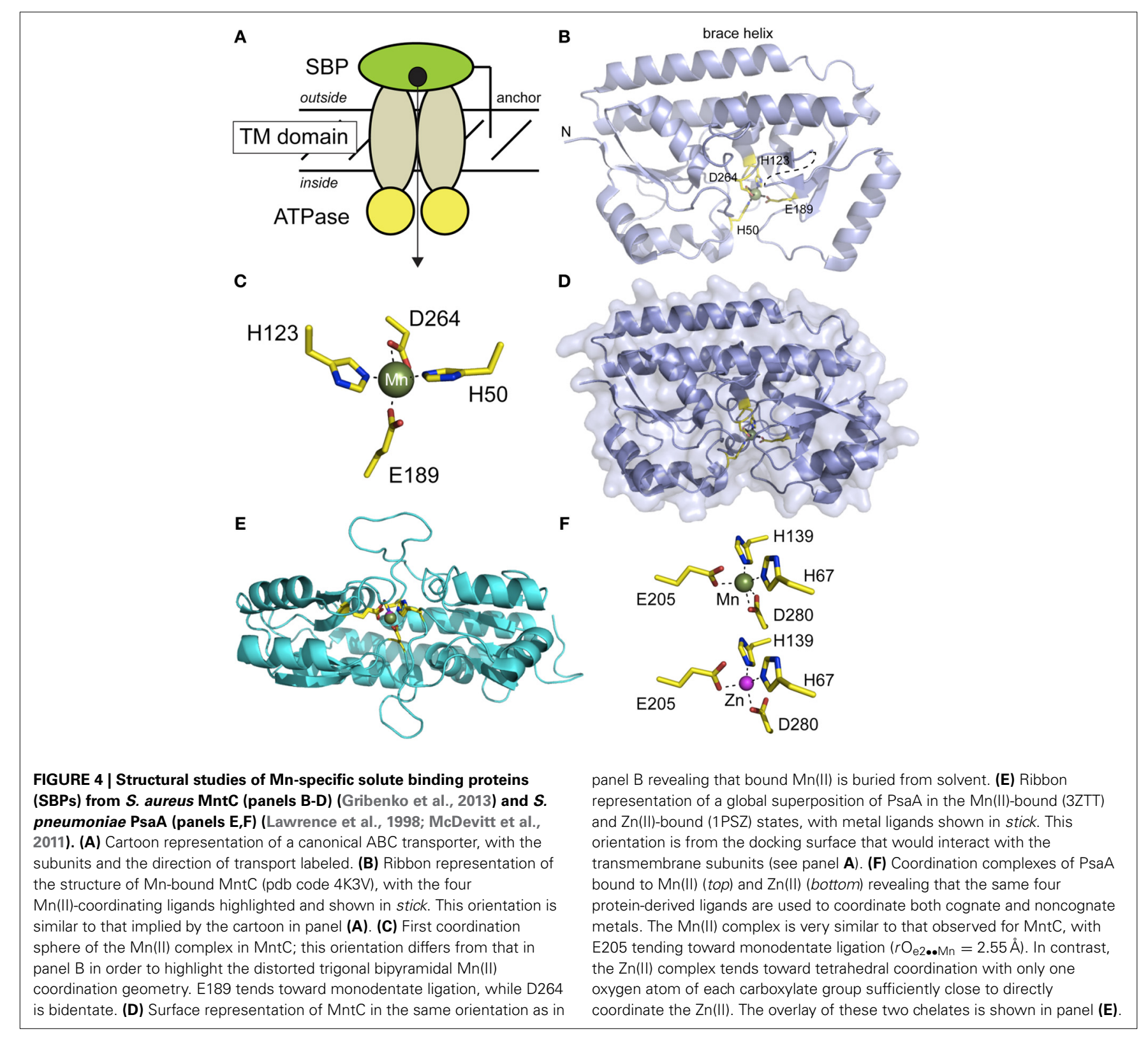

calprotectin (see below). This is also true from the perspective of fundamental inorganic chemistry since $\mathrm{Mn}$ (II) complexes will tend to be far less thermodynamically stable than "isostructural" $\mathrm{Zn}$ (II) complexes (Figure 1A) (Waldron and Robinson, 2009). Metal transport studies have been carried out on bacterial NRAMP1 homologs in S. typhimurium and E. coli and generally show half maximal transport rates at 0.1 to $1 \mu \mathrm{M}$ total $\mathrm{Mn}$ (II) depending on the transporter (Kehres et al., 2000). For ABC transporters, the concentration of any metal that gives maximal rates of transport has not yet been measured to our knowledge; on the other hand, the $\mathrm{Mn}$ (II) and $\mathrm{Zn}$ (II) affinities of the component SBPs have been determined using chelator competition assays or via direct titration by isothermal titration calorimetry (ITC). We compile these values here (Table 1) with the caveat that in an ITC experiment the affinity $\left(K_{\mathrm{d}}\right.$ or $\left.K_{\mathrm{a}}\right)$ is often too tight to measure at the protein concentrations required to make the measurement (Figure 5), despite the ability to obtain a reliable measure of the stoichiometry and the heat of binding $\left(\Delta H_{\text {cal }}\right)$. As can be seen, determined $K_{d}$ Mn values range from the low $\mathrm{nM}$ to several hundred $\mathrm{nM}$, with some indication that $\mathrm{Zn}$ (II) may bind more weakly than $\mathrm{Mn}(\mathrm{II})$ (Desrosiers et al., 2007; McDevitt et al., 2011; Zheng et al., 2011; Gribenko et al., 2013). We note that the $K_{\mathrm{d}}{ }^{\mathrm{Mn}}$ obtained for S. aureus $\mathrm{MntC}$ of $4.0 \pm 0.3 \mathrm{nM}\left(50 \mathrm{mM}\right.$ citrate, $\left.150 \mathrm{mM} \mathrm{NaCl}, \mathrm{pH} 6.0,20^{\circ} \mathrm{C}\right)$ is robust since this value was extracted from a nonstoichiometric binding isotherm acquired in the presence of $50 \mathrm{mM}$ citrate as a $\mathrm{Mn}(\mathrm{II})$ competitor chelator (Gribenko et al., 2013). It will be interesting to learn how $K_{\mathrm{d}}{ }^{\mathrm{Mn}}$ corresponds to $K_{\mathrm{m}}$ for transport, since rapid dissociation of $\mathrm{Mn}(\mathrm{II})$ from the SBP into the transport cavity (Pinkett et al., 2007) upon productive association with the transmembrane domain of the transporter (see Figure 4A) could facilitate rapid movement of $\mathrm{Mn}$ (II) across the membrane 
Table 1 | Equilibrium dissociation constants $\left(K_{d}\right)$ reported for solute binding proteins of Mn-specific ATP-binding cassette transporters and for human calprotectin.

\begin{tabular}{llcc}
\hline Protein & Method & $\mathbf{K}_{\mathbf{d}}(\mathbf{M n}), \mathbf{n M}$ & $\mathbf{K}_{\mathbf{d}}(\mathbf{Z n}), \mathbf{n M}$ \\
\hline Spn PsaA SBP & ITC & $3.3( \pm 0.1)$ & $230( \pm 2)$ \\
Tpa TroA SBP & ITC & $7.1( \pm 0.5)$ & $22( \pm 4)$ \\
Ype YfeA SBP & ITC & $18( \pm 6)$ & $6.7( \pm 1.6)$ \\
Ssu TroA SBPd & ITC & $250( \pm 20)$ & $430( \pm 10)$ \\
Sau MntC SBPe & ITC, competition & $3.8( \pm 1.1)$ & not determined \\
Calprotectin + & chelator comp & $190 ; 21000$ & $<0.01 ;<0.24$ \\
Ca(II) & & & \\
Calprotectin + & ITC & $1.3 ; 3700$ & $1.4 ; 5.5$ \\
Ca(III) & & &
\end{tabular}

a $20 \mathrm{mM} \mathrm{NaH}_{2} \mathrm{PO}_{4}, \mathrm{pH} 6.5,25^{\circ} \mathrm{C}, 4.5-20 \mu \mathrm{M}$ PsaA (McDevitt et al., 2011).

${ }^{b} 100 \mathrm{mM}$ sodium acetate, $\mathrm{pH} 6.5,20^{\circ} \mathrm{C}, 40 \mu \mathrm{M}$ TroA (Desrosiers et al., 2007).

${ }^{c} 100 \mathrm{mM}$ sodium acetate, $\mathrm{pH} 6.5,20^{\circ} \mathrm{C}, 42 \mu \mathrm{M}$ YfeA (Desrosiers et al., 2010).

${ }^{d} 20 \mathrm{mM}$ sodium acetate, $\mathrm{pH} 6.5$ at $25^{\circ} \mathrm{C}, 30$ or $90 \mu \mathrm{M}$ TroA (Zheng et al., 2011).

${ }^{e} 50 \mathrm{mM}$ citrate, $150 \mathrm{mM} \mathrm{NaCl}, 10 \%$ glycerol, pH 6.0, $25^{\circ} \mathrm{C}, 36-43 \mu \mathrm{M} \mathrm{MntC}$ (Gribenko et al., 2013).

${ }^{f} \mathrm{Mn}$ parameters measured in $75 \mathrm{mM}$ Hepes, $100 \mathrm{mM} \mathrm{NaCl}, 0.2 \mathrm{mM} \mathrm{Ca}(I I), \mathrm{pH}$ $7.5,25^{\circ} \mathrm{C}$. Values for metal site 1 (S1; His $)$ and metal site 2 (S2; His ${ }_{3}$ Asp) are shown as $K_{d}^{M n 1}, K_{d}^{M n 2}, K_{d}^{Z n 1}$, and $K_{d}^{Z n 2}$ (Figure 5).

${ }^{g}$ Zn parameters measured in $75 \mathrm{mM}$ Hepes, $100 \mathrm{mM} \mathrm{NaCl}, 1 \mathrm{mM} \mathrm{Ca}(I), \mathrm{pH} 7.5$, room temperature.

${ }^{h}$ Measured in $20 \mathrm{mM}$ Tris, $100 \mathrm{mM} \mathrm{NaCl}, 22.5 \mu \mathrm{M} \mathrm{Ca(II),} 5 \mathrm{mM} \beta$ mercaptoethanol, $\mathrm{pH} 7.5,30^{\circ} \mathrm{C}, 7.5 \mu \mathrm{M} \mathrm{CP}$ (Kehl-Fie et al., 2011). A $\Delta S 1$ mutant $\mathrm{CP}$ does not bind $\mathrm{Mn}$ tightly in contrast to the $\triangle S 2$ mutant, revealing the His 6 S1 site is the high affinity site for Mn (Damo et al., 2013).

not fully reflected in the $\mathrm{Mn}(\mathrm{II})$-binding thermodynamics (Figure 5).

\section{HOST SEOUESTRATION OF TRANSITION METAL IONS}

The mammalian host is a reservoir that is potentially rich in essential nutrients, including transition metals that must be acquired by bacterial pathogens (Versieck, 1985). In many cases, the host limits critical micronutrients such as iron (Weinberg, 1974) through both intracellular and extracellular complexation in an effort to withhold these metals from the invading pathogen (Weinberg, 1975; Hood and Skaar, 2012). For example, lipocalin 2 (Lcn2; siderochalin) binds $\mathrm{Fe}(\mathrm{III})$-enterochelin, carboxymycobactin and bacillibactin complexes in direct competition with the bacterium (E. coli, Mycobacterium tuberculosis, or Bacillus anthracis in this case) that secretes these siderophores to capture bioavailable Fe from the host (Flo et al., 2004; Holmes et al., 2005; Sia et al., 2013). This establishes a competition between host and pathogen for the same metals (Bachman et al., 2009), and consistent with this model, Lcn2 expression and secretion is greatly elevated at sites of infection (Flo et al., 2004), and knockout mice lacking these and other host defenses are more susceptible to bacterial infection (Flo et al., 2004; Corbin et al., 2008; Hammer and Skaar, 2012).

Accumulating evidence assembled over the last several years reveals that a similar competitive strategy is used by the host to restrict the availability of both zinc and manganese in response to bacterial infection (Corbin et al., 2008; Kehl-Fie and Skaar, 2010; Kehl-Fie et al., 2011). This occurs in one of several ways. Macrophages and neutrophils are known to engulf intracellular pathogens in order to isolate them into a phagosomal compartment from which essential metals $\mathrm{Mn}$ and Fe are depleted by efflux, while $\mathrm{Cu}$ is concentrated (Wagner et al., 2005; White et al., 2009; Osman et al., 2010; Achard et al., 2012; Botella et al., 2012). Natural resistance-associated macrophage protein 1 (NRAMP1) (Cellier et al., 2007) and related H+-coupled transporters are known to efflux $\mathrm{Mn}$ (II) and $\mathrm{Fe}$ (II) from intracellular compartments of macrophages (Forbes and Gros, 2001), and knockout mice lacking NRAMP1 are susceptible to more virulent bacterial infections relative to wild-type mice (Skamene et al., 1982).

A number of $S 100$ family proteins are now known to function extracellularly to chelate $\mathrm{Mn}$ (II) and $\mathrm{Zn}$ (II) to sequester these metals from the invading bacterium. For example, the S100A7 homodimer limits growth and invasion at epithelial surfaces through chelation of $\mathrm{Zn}$ (II) (Gläser et al., 2005), although the mechanistic details require further study. More recently it has been established that the heterotetrameric S100A8/S100A9 complex, also known as calprotectin (CP), binds both $\mathrm{Mn}(\mathrm{II})$ and $\mathrm{Zn}$ (II) (Figure 6) and is a major neutrophil-derived protein found in Staphylococcus aureus-induced tissue abscesses (Corbin et al., 2008). Laser ablation (LA)-ICP-MS was used to demonstrate that $\mathrm{Mn}(\mathrm{II})$ and $\mathrm{Zn}$ (II) were undetectable in abscesses relative to the surrounding uninfected tissue in a process dependent on host-encoded S100A8 and S100A9; furthermore, this chelation strategy is synergistic with neutrophil-mediated processes that sensitize these bacteria to superoxide stress by diminishing the effectiveness of Mn-SOD-dependent and independent antioxidant mechanisms (Kehl-Fie et al., 2011). These data support a model in which $\mathrm{CP}$ cripples bacterial defenses to both macrophage and neutrophil-mediated killing, and limits proliferation in tissue abscesses through $\mathrm{Mn}(\mathrm{II})$ chelation. More recent findings suggest that this general chelation strategy is likely operative in other tissues but is CP-independent, revealing that calprotectin may not be the only route that the host can use to limit Mn(II) from invading bacteria (Kehl-Fie et al., 2013). In addition, the degree to which $\mathrm{Zn}(\mathrm{II})$ chelation, relative to $\mathrm{Mn}(\mathrm{II})$, by CP limits bacterial growth is not fully understood, although a recent unbiased mutant screen carried out with the Gram-negative opportunistic respiratory pathogen Acinetobacter baumannii specifically identified components of the zinc acquisition and metabolism systems in that organism when challenged with CP (Hood et al., 2012; Moore et al., 2013).

\section{CALPROTECTIN: STRUCTURAL, METAL BINDING AND FUNCTIONAL PROPERTIES}

Recent studies reveal that CP has widespread antimicrobial activity against many Gram-positive and Gram-negative human pathogens grown in liquid culture, albeit to widely varying degrees, the explanation for which remains incompletely understood (Damo et al., 2013). We have recently shown that CP inhibits the growth of both wild-type and encapsulated strains of Streptococcus pneumoniae D39, extending the range of this broad spectrum antimicrobial activity (Lisher et al., unpublished). One simple explanation is that more resistant bacteria express $\mathrm{Mn}$ (II) uptake systems that possess a higher affinity than CP for $\mathrm{Mn}$ (II) and thus will compete more effectively with $\mathrm{CP}$ for extracellular 


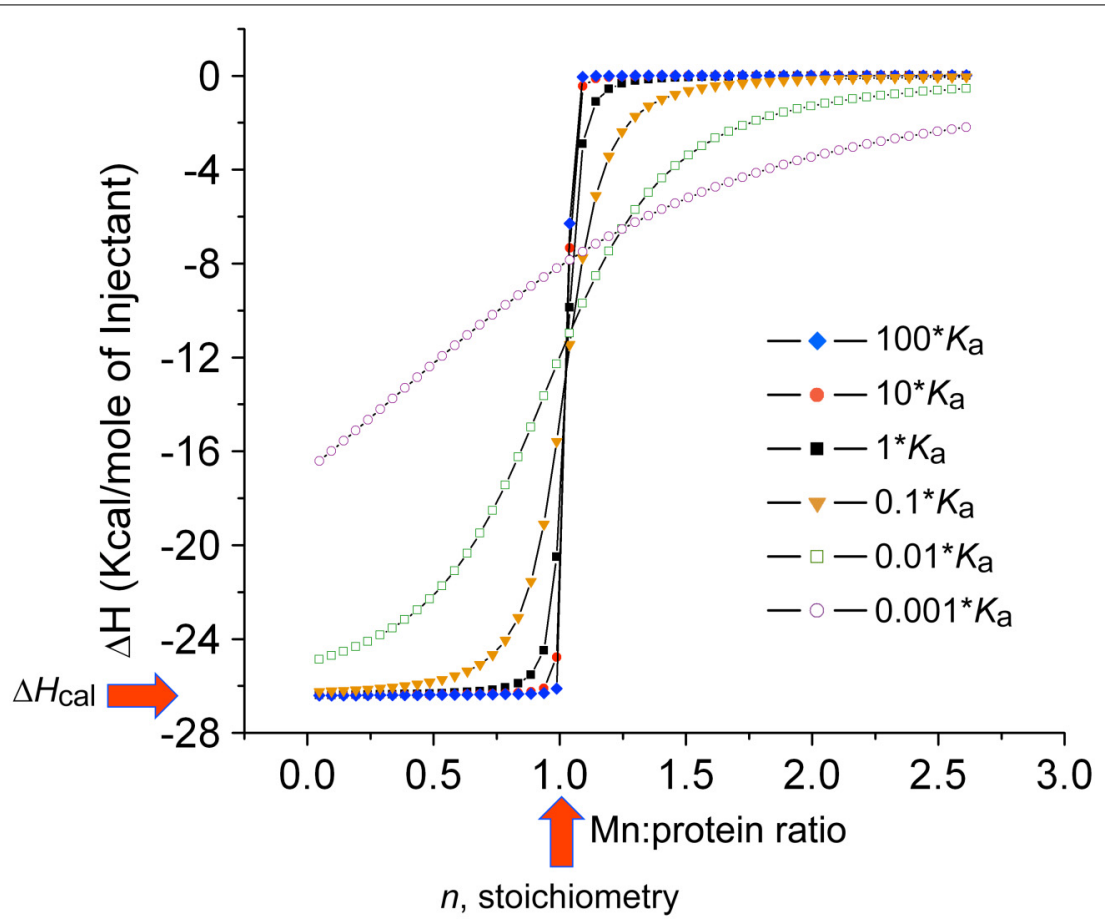

FIGURE 5 | Simulated binding curves for ITC thermograms using the reported thermodynamics and injection volumes of the $\mathrm{MnCl}_{2}$ binding to the $\mathbf{S} \boldsymbol{\Delta} \mathbf{2}$ mutant of $\mathbf{C P}$ (Damo et al., 2013). The simulated curve that corresponds to the reported $K_{d}$ of $5.8 \mathrm{nM}$ (at $10 \mu \mathrm{M}$ total CP heterodimer), $n=1.0$ (red vertical arrow) and $\Delta H_{\text {cal }}=26.2 \mathrm{kcal} \mathrm{mol}^{-1}$ (red horizontal arrow) was converted to $K_{a}\left(1.7 \times 10^{8} \mathrm{M}^{-1}\right)$ to create the isotherm labeled $1 \bullet K_{a}$ (black squares). Other simulated curves are shown for $K_{a}$ for $10-\left(10 * K_{a}\right)$ and 100 -fold $\left(100 * K_{\mathrm{a}}\right)$ higher $K_{\mathrm{a}}$, and $10-\left(0.1 * K_{\mathrm{a}}\right), 100-\left(0.01 * K_{\mathrm{a}}\right)$ and 1000 -fold $\left(0.001 * K_{\mathrm{a}}\right)$ lower $K_{\mathrm{a}}$. These simulations reveal that binding affinities greater than $\approx 10^{8}$ $\mathrm{M}^{-1}\left(K_{\mathrm{d}} \leq 10 \mathrm{nM}\right)$ can not be reliably measured under these conditions, and are indicative of essentially stoichiometric binding as evidenced by a paucity of data points in the transition region. At 5-10-fold-higher concentration of protein, which is more typical of the SBP-Mn(II) measurements in the literature (see Table 1), a $K_{\mathrm{a}}>10^{7} \mathrm{M}^{-1}\left(K_{\mathrm{d}}<100 \mathrm{nM}\right)$ will not be reliably measured unless a chelator competitor, e.g., citrate for $\mathrm{Mn}(\mathrm{II})$, is used to measure $K_{\mathrm{a}}^{\mathrm{Mn}}$ (Grossoehme and Giedroc, 2009; Gribenko et al., 2013).

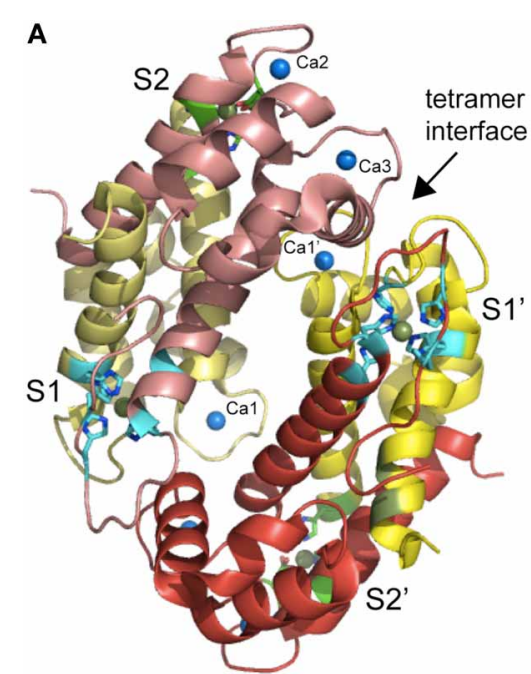

FIGURE 6 | Ribbon representation of the structure of the Mn(II)-bound CP heterotetramer (A) and S100A8-S100A9 heterodimer (B) (Damo et al., 2013). S100A8 chains are shaded in yellow and pale yellow, while S100A9 chains are shaded in red and salmon. The tetramer interface between the two heterodimers is marked. The two intersubunit $\mathrm{Mn}$ ions per heterodimer
B

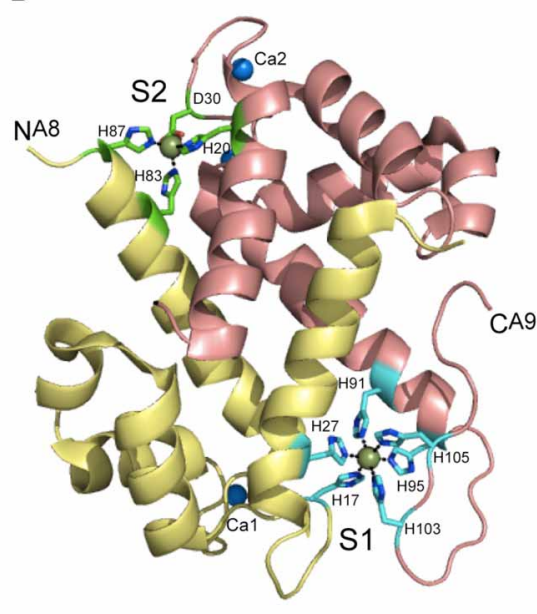

are shown as smudge spheres and the three $\mathrm{Ca}(\mathrm{II})$ ions per dimer are shown as blue spheres and labeled $\mathrm{Ca} 1$ bound to $\mathrm{S} 100 \mathrm{~A} 8, \mathrm{Ca} 2$ and $\mathrm{Ca} 3$, both bound to S100A9. The coordinating ligands to both S1 and S2 Mn(II) ions are shown in stick representation are labeled with residue number; one of the two S2 sites showed partial occupancy in the structure. 
$\mathrm{Mn}(\mathrm{II})$. This requires knowledge of the structure and $\mathrm{Mn}$ (II) and $\mathrm{Zn}(\mathrm{II})$ binding affinities of CP. Initial studies established that a single S100A8/S100A9 heterodimer is capable of binding two molar equivalents of transition metal, designated $S 1$ and S2; however, while $\mathrm{Zn}$ (II) could fill both sites, $\mathrm{Mn}$ (II) could fill only one with high affinity (S1) (Kehl-Fie et al., 2011). The same is true in the context of the heterotetramer $\left(\mathrm{S} 100 \mathrm{~A} 8_{2}\right.$ S100 $\mathrm{A}_{2}$ ) which is well-modeled in metal binding experiments as two functionally independent heterodimers (Figure 6). Estimates of the metal binding affinity obtained in the presence of calcium from ITC show essentially stoichiometric binding at $\mathrm{pH}$ 7.5 with reported values of $K_{\mathrm{d}}^{\mathrm{Zn} 1}=1.4 \mathrm{nM}$ and $K_{\mathrm{d}}^{\mathrm{Zn} 2}=5.6 \mathrm{nM}$ (Table 1). For $\mathrm{Mn}(\mathrm{II})$, reported values are $K_{\mathrm{d}}{ }^{\mathrm{Mn} 1}=1.3 \mathrm{nM}$ and a $K_{\mathrm{d}}^{\mathrm{Mn} 2}=3.7 \mu \mathrm{M}$ (Table 1 ). For reasons discussed above, $\mathrm{nM}$ values measured by ITC may well-reflect lower limits of $K_{\mathrm{a}}$ and correspondingly upper limits on $K_{\mathrm{d}}$ (see Figure 5). Indeed, subsequent metal competition experiments that employed a fluorescent sensor ZP4 ( $K_{\mathrm{Zn}}=0.65 \mathrm{nM}$; measurable range in $K_{\mathrm{Zn}}$ of $0.01-10 \mathrm{nM})$ as a competitor ligand for $\mathrm{Zn}(\mathrm{II})$ revealed $K_{\mathrm{d}}{ }^{\mathrm{Zn} 1}=$ $0.13 \mathrm{nM}$ and $K_{\mathrm{d}}^{\mathrm{Zn} 2}=185 \mathrm{nM}(-\mathrm{Ca})$ and $K_{\mathrm{d}}^{\mathrm{Zn} 1} \leq 0.01 \mathrm{nM}$ and $K_{\mathrm{d}}^{\mathrm{Zn} 2} \leq 0.24 \mathrm{nM}$ (+Ca) (Brophy et al., 2012), both significantly tighter than estimates from ITC. Room-temperature Mn(II) EPR titrations reveal $K_{\mathrm{d}}^{\mathrm{Mn} 1}$ of $4.9 \mu \mathrm{M}$ and $K_{\mathrm{d}}^{\mathrm{Mn} 2}=1.0 \mathrm{mM}$ in the absence of calcium (Hayden et al., 2013) which shift to $\approx 200 \mathrm{nM}$ and $21 \mu \mathrm{M}$ in the presence of calcium (Table 1 ). These studies taken collectively reveal that calcium binding "switches on" $\mathrm{CP}$ to become a high affinity $\mathrm{Zn} / \mathrm{Mn}$ binding protein with the major antimicrobial form of CP likely the mixed Mn (S1)/Zn (S2) heterotetramer (Hayden et al., 2013).

Crystallographic and mutagenesis experiments establish an unprecedented hexahistidine-coordinated (His ${ }_{6}$ ) Mn(II) site conforming to octahedral coordination geometry (Hayden et al., 2013) as the high affinity (S1) Mn(II) site, with the $\mathrm{Zn}$ (II) site (S2) adopting a tetrahedral His 3 -Asp complex (Damo et al., 2013) (Figure 6B). Two of the six histidines in the $\mathrm{His}_{6}$ site are derived from the conserved His103 and His105 in the C-terminal tail of S100A9 both of which are essential for antimicrobial function (Damo et al., 2013). The close proximity of these tail ligands to one of the $\mathrm{Ca}(\mathrm{II})$ binding sites immediately explains the strong calcium-dependent increase in $\mathrm{Mn}$ (II) binding affinity (Brophy et al., 2012). The broad-spectrum antimicrobial activity CP is largely dependent on the integrity of this $\mathrm{S} 1 \mathrm{His}_{6}$ site rather than the S2 $\mathrm{Zn}$ (II) site, thus likely connecting Mn(II) sequestration to the biological activity of CP. Although CP may have a lower affinity for Mn(II) than bacterially encoded SBPs (Table 1), the degree to which $\mathrm{Mn}$ (II) is coordinated by CP vs. SBPs or other $\mathrm{Mn}$ (II) import transporters is of course dictated by mass action which is set by the relative effective concentrations of each "chelator" in the milieu. Subsequent findings from Skaar and coworkers are consistent with this direct competition model, in that CP-imposed Mn(II) starvation increases the expression of a constitutively expressed NRAMP1-like manganese transporter, $\mathrm{MntH}$, as well as the ABC family importer, MntABC, of which MntC is the Mn(II)-binding subunit (Kehl-Fie et al., 2013) (see Figure 4B). Both uptake systems are required to fully resist the effects of CP-dependent metal limitation since the $\mathrm{IC}_{50}$ for $\mathrm{CP}$ of an $\Delta m n t C / \Delta m n t H$ stain was $\approx 50 \%$ lower than a $S$. aureus wild-type strain; additionally, both importers were required for resistance to superoxide stress as a result of increased SOD activity, and the ability of $S$. aureus to establish a systemic infection (Kehl-Fie et al., 2013). This "tug-of war" used to tip the balance of mass action in favor of the pathogen relative to $\mathrm{Mn}$ (II) acquisition may well be a general one (Champion et al., 2011).

\section{THE IMPACT OF OTHER TRANSITION METALS ON MANGANESE ACOUISITION AND HOMEOSTASIS}

In addition to competition from host proteins of the innate immune response, there is some evidence that $\mathrm{Zn}(\mathrm{II})$ and $\mathrm{Fe}(\mathrm{II})$ can influence $\mathrm{Mn}$ (II) acquisition and intracellular $\mathrm{Mn}$ (II)dependent metalloregulation of transcription. For example, $\mathrm{Zn}$ (II) has been shown to inhibit $\mathrm{Mn}$ (II) uptake by binding irreversibly to S. pneumoniae PsaA and effectively blocks $\mathrm{Mn}$ (II) transport into the cytoplasm (McDevitt et al., 2011). This induces an intracellular $\mathrm{Mn}$ (II) deficiency leading to upregulation of the expression of the entire PsaR regulon, as part of an effort to scavenge $\mathrm{Mn}$ (II) from the environment (Kloosterman et al., 2008; Jacobsen et al., 2011). In addition, $\mathrm{Zn}$ (II) is capable of binding to the $\mathrm{Mn}$ (II) sensor PsaR, converting PsaR into a poorly active repressor (Lisher et al., 2013) thereby minimizing transcriptional repression of $p s a B C A$ under these conditions (Jacobsen et al., 2011). Both of these effects can be reversed by the addition of $\mathrm{Mn}$ (II) to the growth media, suggesting the possibility that the pneumococcus may use one or both mechanisms to maintain a favorable intracellular $\mathrm{Zn}(\mathrm{II}): \mathrm{Mn}$ (II) ratio under conditions of high extracellular zinc toxicity that might occur in the lung, for example (McDevitt et al., 2011). Like PsaR (Lisher et al., 2013), other structurally related $\mathrm{Mn}$ (II)-specific metalloregulatory proteins, e.g., B. subtilis MntR, also bind $\mathrm{Zn}(\mathrm{II})$ with significantly higher affinity ( $\geq 100$-fold), a finding consistent with the IrvingWilliams series (Figure 1A) (Golynskiy et al., 2006; Maret, 2010; Ma et al., 2012), yet the $\mathrm{Zn}(\mathrm{II})$-bound repressor binds much more weakly to the DNA operator than the cognate $\mathrm{Mn}$ (II)bound repressor (Lieser et al., 2003). The degree to which this competition in the cell is a general strategy to modulate $\mathrm{Mn}$ (II) homeostasis under conditions of zinc toxicity is unknown.

Intracellular crosstalk between $\mathrm{Fe}$ (II) and $\mathrm{Mn}$ (II) homeostasis systems may well be more relevant to bacterial cell physiology and pathogenesis than is $\mathrm{Zn}$ (II)-Mn(II) crosstalk. These two metals lie at the same weakly competitive end of the Irving-Williams series and the Fe:Mn ratio might be considered a reporter of microbial lifestyle, capable of altering the altering the resistance of an organism to ROS (see Figure 1). As discussed above, a LMW-Mn(II) pool may well be present is most bacterial cells, albeit to differing degrees (Sharma et al., 2013), and some cells contain a chelatable pool of several hundred micromolar Fe(II) that is detectable by EPR spectroscopy of whole cells (Pericone et al., 2003). Thus, changes in the Mn:Fe ratio by upregulation of the $\mathrm{Mn}$ (II) acquisition system (Figure 2), or by crippling Fe(II) uptake repression in a fur mutant, for example, might be expected to change the metal specificity of an $\mathrm{Fe}(\mathrm{II})$ - or $\mathrm{Mn}$ (II)-specific metal-sensing repressor (Guedon and Helmann, 2003; Ma et al., 2011, 2012) and selected metalloenzymes (Whittaker, 2003; Anjem et al., 2009). This kind of $\mathrm{Mn}(\mathrm{II})-\mathrm{Fe}(\mathrm{II})$ regulatory crosstalk is exemplified by recent work in B. subtilis on $\mathrm{Mn}$ (II)-MntR and two related Fur family members, the peroxide sensing, Fe(II)-binding PerR (see Figure 2) and the Fe(II)-sensing repressor Fur (Ma et al., 
2011, 2012). It was reported that selected mutations of PerR introduced into a nonfunctional metal site (found in other Fur family proteins) close to the primary Fe(II) binding site altered the structure of PerR such that Mn(II) bound more tightly then $\mathrm{Fe}(\mathrm{II})$. Strains harboring these mutations were correspondingly more sensitive to peroxide stress since $\mathrm{Mn}$ (II)-PerR thus formed is unable to perform peroxide-catalyzed autooxidation which drives transcriptional derepression of the perR regulon. Remarkably, FePerR-dependent $\mathrm{H}_{2} \mathrm{O}_{2}$-sensing was restored in this mutant in a fur mutant background, presumably allowing $\mathrm{Fe}$ (II) levels to rise to a level sufficient level to fill the mutant PerR regulatory site with cognate Fe(II) (Ma et al., 2011).

A second example concerns B. subtilis Fur itself (Ma et al., 2012). In this study, it was shown that cognate Fe(II) and noncognate metals $\mathrm{Mn}$ (II) and $\mathrm{Zn}$ (II) are equally effective in activating Fur to bind to its DNA operator in vitro; however, Fur is Fe(II)specific in vivo. Remarkably, this $\mathrm{Fe}(\mathrm{II})$-specificity is lost in a perR mutant strain. Here, the combined impact of increasing Fur concentrations and intracellular $\mathrm{Mn}$ (II) levels relative to $\mathrm{Fe}$ (II), leads to conditions where Fur binds Mn(II), which in turn, leads to inappropriate $\mathrm{Mn}$ (II)-mediated repression of the fur regulon, including genes responsible for $\mathrm{Fe}(\mathrm{II})$ uptake. Thus, PerR may directly impact Fe(II) homeostasis by modulating Fur levels in response to a change in the $\mathrm{Mn}: \mathrm{Fe}$ ratio, i.e., that which might occur under conditions of high $\mathrm{Mn}$ (II) and Fe(II)-deplete conditions (see Figure 2).

Although the degree to which Fe(II)-Mn(II) crosstalk influences bacterial pathogenesis is not firmly established, a number of recent studies suggest that maintenance of an optimal $\mathrm{Mn}(\mathrm{II}): \mathrm{Fe}$ (II) ratio can impact the virulence of pathogenic bacteria. For example, the ability of $S$. pneumoniae to maintain a high $\mathrm{Mn}(\mathrm{II}): \mathrm{Fe}(\mathrm{II})$ ratio (Jacobsen et al., 2011) (Figure 1B) may be relevant to resistance to oxidative stress important for pathogenesis of this organism (Ong et al., 2013). In Yersinia pestis, the manganese import systems Yfe and $\mathrm{MntH}$ are regulated by Fe-Fur and loss of these systems leads to reduced virulence in sepsis models (Perry et al., 2012). In Neisseria meningitidis, a novel efflux protein, $\mathrm{MntX}$, that maintains optimal $\mathrm{Mn}(\mathrm{II}): \mathrm{Fe}(\mathrm{II})$ ratios under conditions of low iron is also critical to virulence in sepsis models (Veyrier et al., 2011); this ensures that Fe(II) will remain bioavailable following conditions of high $\mathrm{Mn}$ (II) import in response to oxidative stress (see Figure 2). Interestingly, Streptococcus pneumoniae, like Neisseria meningitidis, also encodes a Mn(II) effluxer, $\mathrm{MntE}$, that is required for virulence (Rosch et al., 2009). It will be interesting to see if the presence of a dedicated manganese effluxer represents a general strategy of providing a "release valve" to avert the effects of high intracellular Mn(II) particularly in Mn-centric bacterial pathogens (see Figure 1B).

\section{CONCLUDING REMARKS}

Recent studies of bacterial transition metal physiology and crosstalk places manganese acquisition by human microbial pathogens on center stage of the host-pathogen "arms race" (Botella et al., 2012). Mn(II) functions to metallate key enzymes, notably Mn-SOD that are responsible for the long-appreciated antioxidant properties of this metal. Recent insights from the application of sophisticated spectroscopies capable of probing Mn(II)-speciation in whole cells (Sharma et al., 2013), coupled with chemical investigations, provide strong support for the proposal that specific LMW-Mn complexes are catalytically competent and functionally important in clearing superoxide from cells, in a way that supplements SOD-dependent mechanisms (Barnese et al., 2012). The discovery of host immune proteins that limit biologically available $\mathrm{Mn}$ (II) for both intracellular and extracellular pathogens in an effort to cripple the resistance of invading pathogens to ROS establishes this as a general strategy used by the host to curtail bacterial infections (Corbin et al., 2008; Damo et al., 2013; Kehl-Fie et al., 2013).

Although structural and biophysical studies provide general support for a simple competition model in which the extracellular chelator calprotectin and $\mathrm{Mn}$ (II)-specific uptake systems compete for the same metal on the basis of their respective affinities, there is much more to be learned about this process. This includes elucidation of the rates and rate-limiting steps of $\mathrm{Mn}$ (II) transport, and structural studies of intact bacterial $\mathrm{ABC}$ transporters positioned at the "front line" of Mn(II) acquisition. This is particularly interesting since $\mathrm{Mn}$ (II) is generally handicapped relative to other divalent metal ions, notably $\mathrm{Zn}$ (II), in chelate stability, and as a result, other factors including formation of kinetically trapped $\mathrm{Mn}$ (II) metalloenzyme complexes in the cell (Whittaker, 2003; Tottey et al., 2008), may well be operative. In this context, it is interesting to note the Streptococcus pneumoniae expresses polyhistidine triad proteins (Pht) proteins attached on the cell surface known to bind zinc (Riboldi-Tunnicliffe et al., 2005) and thus could be used to scavenge $\mathrm{Zn}$ (II) from the host milieu under conditions of zinc limitation (Reyes-Caballero et al., 2010; Shafeeq et al., 2011; Plumptre et al., 2012, 2013). A bonus role for these proteins is that they could be used sequester $\mathrm{Zn}$ (II) and thereby reduce competition at the manganese importer PsaBCA, allowing pneumococcus to efficiently obtain $\mathrm{Mn}$ (II) which is likely bioavailable at vanishingly small quantities relative to $\mathrm{Zn}$ (II) (Shafeeq et al., 2013).

Further insights into molecular mechanisms of host nutritional immunity against bacterial pathogens will continue to rely on concerted and collaborative efforts of microbiologists, coordination chemists and structural biologists in an effort to win the "tug-of-war" over transition metals at the host-pathogen interface through the development of intervention strategies based on metals in biology of infectious disease.

\section{AUTHOR CONTRIBUTIONS}

John P. Lisher and David P. Giedroc wrote the manuscript.

\section{ACKNOWLEDGMENTS}

Work in the authors laboratory on bacterial transition metal homeostasis is supported by a grant from the US National Institutes of Health (R01 GM042569 to David P. Giedroc). John P. Lisher acknowledges support from the Quantitative and Chemical Biology Training Program at Indiana University.

\section{REFERENCES}

Abrantes, M. C., Kok, J., and Lopes Mde, F. (2013). EfaR is a major regulator of Enterococcus faecalis manganese transporters and influences processes involved in host colonization and infection. Infect. Immun. 81, 935-944. doi: 10.1128/IAI.06377-11

Achard, M. E., Stafford, S. L., Bokil, N. J., Chartres, J., Bernhardt, P. V., Schembri, M. A., et al. (2012). Copper redistribution in murine macrophages 
in response to Salmonella infection. Biochem. J. 444, 51-57. doi: 10.1042/BJ20 112180

Aguirre, J. D., Clark, H. M., McIlvin, M., Vazquez, C., Palmere, S. L., Grab, D. J., et al. (2013). A manganese-rich environment supports superoxide dismutase activity in a Lyme disease pathogen, Borrelia burgdorferi. J. Biol. Chem. 288, 8468-8478. doi: 10.1074/jbc.M112.433540

Aguirre, J. D., and Culotta, V. C. (2012). Battles with iron: manganese in oxidative stress protection. J. Biol. Chem. 287, 13541-13548. doi: 10.1074/jbc.R111.312181

Al-Maghrebi, M., Fridovich, I., and Benov, L. (2002). Manganese supplementation relieves the phenotypic deficits seen in superoxide-dismutase-null Escherichia coli. Arch. Biochem. Biophys. 402, 104-109. doi: 10.1016/S0003-9861(02) 00065-6

Andreini, C., Bertini, I., Cavallaro, G., Holliday, G. L., and Thornton, J. M. (2008). Metal ions in biological catalysis: from enzyme databases to general principles. J. Biol. Inorg. Chem. 13, 1205-1218. doi: 10.1007/s00775-008-0404-5

Andrews, S. C., Robinson, A. K., and Rodríguez-Quiñones, F. (2003). Bacterial iron homeostasis. FEMS Microbiol. Rev. 27, 215-237. doi: 10.1016/S01686445(03)00055-X

Anjem, A., and Imlay, J. A. (2012). Mononuclear Iron Enzymes Are Primary Targets of Hydrogen Peroxide Stress. J. Biol. Chem. 287, 15544-15556. doi: 10.1074/jbc.M111.330365

Anjem, A., Varghese, S., and Imlay, J. A. (2009). Manganese import is a key element of the OxyR response to hydrogen peroxide in Escherichia coli. Mol. Microbiol. 72, 844-858. doi: 10.1111/j.1365-2958.2009.06699.x

Archibald, F. S., and Fridovich, I. (1981a). Manganese and defenses against oxygen toxicity in Lactobacillus plantarum. J. Bacteriol. 145, 442-451.

Archibald, F. S., and Fridovich, I. (1981b). Manganese, superoxide dismutase, and oxygen tolerance in some lactic acid bacteria. J. Bacteriol. 146, 928-936.

Ardini, M., Fiorillo, A., Fittipaldi, M., Stefanini, S., Gatteschi, D., Ilari, A., et al. (2013). Kineococcus radiotolerans Dps forms a heteronuclear Mn-Fe ferroxidase center that may explain the Mn-dependent protection against oxidative stress. Biochim. Biophys. Acta 1830, 3745-3755. doi: 10.1016/j.bbagen.2013.02.003

Bachman, M. A., Miller, V. L., and Weiser, J. N. (2009). Mucosal lipocalin 2 has pro-inflammatory and iron-sequestering effects in response to bacterial enterobactin. PLoS Pathog. 5:e1000622. doi: 10.1371/journal.ppat.1000622

Banerjee, S., Wei, B., Bhattacharyya-Pakrasi, M., Pakrasi, H. B., and Smith, T. J. (2003). Structural determinants of metal specificity in the zinc transport protein ZnuA from Synechocystis 6803. J. Mol. Biol. 333, 1061-1069. doi: 10.1016/j.jmb.2003.09.008

Barnese, K., Gralla, E. B., Cabelli, D. E., and Valentine, J. S. (2008). Manganous phosphate acts as a superoxide dismutase. J. Am. Chem. Soc. 130, 4604-4606. doi: $10.1021 /$ ja710162n

Barnese, K., Gralla, E. B., Valentine, J. S., and Cabelli, D. E. (2012). Biologically relevant mechanism for catalytic superoxide removal by simple manganese compounds. Proc. Natl. Acad. Sci. U.S.A. 109, 6892-6897. doi: 10.1073/pnas. 1203051109

Berntsson, R. P., Smits, S. H., Schmitt, L., Slotboom, D. J., and Poolman, B. (2010). A structural classification of substrate-binding proteins. FEBS Lett. 584, 2606-2617. doi: 10.1016/j.febslet.2010.04.043

Botella, H., Stadthagen, G., Lugo-Villarino, G., de Chastellier, C., and Neyrolles, O. (2012). Metallobiology of host-pathogen interactions: an intoxicating new insight. Trends Microbiol. 20, 106-112. doi: 10.1016/j.tim.2012.01.005

Brophy, M. B., Hayden, J. A., and Nolan, E. M. (2012). Calcium ion gradients modulate the zinc affinity and antibacterial activity of human calprotectin. J. Am. Chem. Soc. 134, 18089-18100. doi: 10.1021/ja307974e

Brown, J. S., Ogunniyi, A. D., Woodrow, M. C., Holden, D. W., and Paton, J. C. (2001). Immunization with components of two iron uptake ABC transporters protects mice against systemic Streptococcus pneumoniae infection. Infect. Immun. 69, 6702-6706. doi: 10.1128/IAI.69.11.6702-6706.2001

Cellier, M. F. (2012). Nramp: from sequence to structure and mechanism of divalent metal import. Curr. Top. Membr. 69, 249-293. doi: 10.1016/B978-012-394390-3.00010-0

Cellier, M. F., Courville, P., and Campion, C. (2007). Nramp1 phagocyte intracellular metal withdrawal defense. Microbes Infect. 9, 1662-1670. doi: 10.1016/j. micinf.2007.09.006

Champion, O. L., Karlyshev, A., Cooper, I. A., Ford, D. C., Wren, B. W., Duffield, M., et al. (2011). Yersinia pseudotuberculosis $\mathrm{mntH}$ functions in intracellular manganese accumulation, which is essential for virulence and survival in cells expressing functional Nramp1. Microbiology 157, 1115-1122. doi: 10.1099/mic.0.045807-0

Chandra, B. R., Yogavel, M., and Sharma, A. (2007). Structural analysis of ABCfamily periplasmic zinc binding protein provides new insights into mechanism of ligand uptake and release. J. Mol. Biol. 367, 970-982. doi: 10.1016/j.jmb.2007. 01.041

Chang, E. C., and Kosman, D. J. (1989). Intracellular Mn (II)-associated superoxide scavenging activity protects $\mathrm{Cu}, \mathrm{Zn}$ superoxide dismutasedeficient Saccharomyces cerevisiae against dioxygen stress. J. Biol. Chem. 264, 12172-12178.

Corbin, B. D., Seeley, E. H., Raab, A., Feldmann, J., Miller, M. R., Torres, V. J., et al. (2008). Metal chelation and inhibition of bacterial growth in tissue abscesses. Science 319, 962-965. doi: 10.1126/science.1152449

Cotruvo, J. A. Jr., and Stubbe, J. (2012). Metallation and mismetallation of iron and manganese proteins in vitro and in vivo: the class I ribonucleotide reductases as a case study. Metallomics 4, 1020-1036. doi: 10.1039/c2mt20142a

Couñago, R. M., Ween, M. P., Begg, S. L., Bajaj, M., Zuegg, J., O’Mara, M. L., et al. (2013). Imperfect coordination chemistry facilitates metal ion release in the Psa permease. Nat. Chem. Biol. 9. doi: 10.1038/nchembio.1382. [Epub ahead of print].

Culotta, V. C., Yang, M., and O'Halloran, T. V. (2006). Activation of superoxide dismutases: putting the metal to the pedal. Biochim. Biophys. Acta 1763, 747-758. doi: 10.1016/j.bbamcr.2006.05.003

Daly, M. J., Gaidamakova, E. K., Matrosova, V. Y., Kiang, J. G., Fukumoto, R., Lee, D. Y., et al. (2010). Small-molecule antioxidant proteome-shields in Deinococcus radiodurans. PLoS ONE 5:e12570. doi: 10.1371/journal.pone.0012570

Daly, M. J., Gaidamakova, E. K., Matrosova, V. Y., Vasilenko, A., Zhai, M., Venkateswaran, A., et al. (2004). Accumulation of $\mathrm{Mn}$ (II) in Deinococcus radiodurans facilitates gamma-radiation resistance. Science 306, 1025-1028. doi: 10.1126/science.1103185

Damo, S. M., Kehl-Fie, T. E., Sugitani, N., Holt, M. E., Rathi, S., Murphy, W. J., et al. (2013). Molecular basis for manganese sequestration by calprotectin and roles in the innate immune response to invading bacterial pathogens. Proc. Natl. Acad. Sci. U.S.A. 110, 3841-3846. doi: 10.1073/pnas.1220341110

Desrosiers, D. C., Bearden, S. W., Mier, I. Jr., Abney, J., Paulley, J. T., Fetherston, J. D., et al. (2010). Znu is the predominant zinc importer in Yersinia pestis during in vitro growth but is not essential for virulence. Infect. Immun. 78, 5163-5177. doi: 10.1128/IAI.00732-10

Desrosiers, D. C., Sun, Y. C., Zaidi, A. A., Eggers, C. H., Cox, D. L., and Radolf, J. D. (2007). The general transition metal (Tro) and $\mathrm{Zn} 2+(\mathrm{Znu})$ transporters in Treponema pallidum: analysis of metal specificities and expression profiles. Mol. Microbiol. 65, 137-152. doi: 10.1111/j.1365-2958.2007.05771.x

DeWitt, M. A., Kliegman, J. I., Helmann, J. D., Brennan, R. G., Farrens, D. L., and Glasfeld, A. (2007). The conformations of the manganese transport regulator of Bacillus subtilis in its metal-free state. J. Mol. Biol. 365, 1257-1265. doi: 10.1016/j.jmb.2006.10.080

Dintilhac, A., and Calverys, J. P. (1997). The adc locus, which affects competence for genetic transformation in Streptococcus pneumoniae, encodes an $\mathrm{ABC}$ transporter with a putative lioprotein homologus to a family of streptococcal adhesins. Res. Microbiol. 148, 119-131. doi: 10.1016/S0923-2508 (97)87643-7

Dudev, T., and Lim, C. (2013). Competition among metal ions for protein binding sites: determinants of metal ion selectivity in proteins. Chem. Rev. doi: $10.1021 / \mathrm{cr} 4004665$. [Epub ahead of print].

Flo, T. H., Smith, K. D., Sato, S., Rodriguez, D. J., Holmes, M. A., Strong, R. K., et al. (2004). Lipocalin 2 mediates an innate immune response to bacterial infection by sequestrating iron. Nature 432, 917-921. doi: 10.1038/ nature 03104

Forbes, J. R., and Gros, P. (2001). Divalent-metal transport by NRAMP proteins at the interface of host-pathogen interactions. Trends Microbiol. 9, 397-403. doi: 10.1016/S0966-842X(01)02098-4

Fraústo da Silva, J., and Williams, R. (2001). The Biological Chemistry of Elements: The Inorganic Chemistry of Life. Oxford: Oxford University Press.

Gherasim, C., Lofgren, M., and Banerjee, R. (2013). Navigating the B(12) road: assimilation, delivery, and disorders of cobalamin. J. Biol. Chem. 288, 13186-13193. doi: 10.1074/jbc.R113.458810

Giedroc, D. P., and Arunkumar, A. I. (2007). Metal sensor proteins: nature's metalloregulated allosteric switches. Dalton Trans. 29, 3107-3120. doi: 10.1039/b706769k 
Gläser, R., Harder, J., Lange, H., Bartels, J., Christophers, E., and Schröder, J. M. (2005). Antimicrobial psoriasin (S100A7) protects human skin from Escherichia coli infection. Nat. Immunol. 6, 57-64. doi: 10.1038/ni1142

Gold, B., Rodriguez, G. M., Marras, S. A., Pentecost, M., and Smith, I. (2001). The Mycobacterium tuberculosis IdeR is a dual functional regulator that controls transcription of genes involved in iron acquisition, iron storage and survival in macrophages. Mol. Microbiol. 42, 851-865. doi: 10.1046/j.13652958.2001.02684.x

Golynskiy, M. V., Gunderson, W. A., Hendrich, M. P., and Cohen, S. M. (2006). Metal binding studies and EPR spectroscopy of the manganese transport regulator MntR. Biochemistry 45, 15359-15372. doi: 10.1021/bi0 607406

Gray, M. J., Wholey, W. Y., and Jakob, U. (2013). Bacterial responses to reactive chlorine species. Annu. Rev. Microbiol. 67, 141-160. doi: 10.1146/annurevmicro-102912-142520

Gribenko, A., Mosyak, L., Ghosh, S., Parris, K., Svenson, K., Moran, J., et al. (2013). Three-dimensional structure and biophysical characterization of Staphylococcus aureus cell surface antigen-manganese transporter MntC. J. Mol. Biol. 425, 3429-3445. doi: 10.1016/j.jmb.2013.06.033

Grossoehme, N. E., and Giedroc, D. P. (2009). Energetics of allosteric negative coupling in the zinc sensor S. aureus CzrA. J. Am. Chem. Soc. 131, 17860-17870. doi: $10.1021 /$ ja906131b

Gu, M., and Imlay, J. A. (2011). The SoxRS response of Escherichia coli is directly activated by redox-cycling drugs rather than by superoxide. Mol. Microbiol. 79, 1136-1150. doi: 10.1111/j.1365-2958.2010.07520.x

Guedon, E., and Helmann, J. D. (2003). Origins of metal ion selectivity in the DtxR/MntR family of metalloregulators. Mol. Microbiol. 48, 495-506. doi: 10.1046/j.1365-2958.2003.03445.x

Haider, B. A., and Bhutta, Z. A. (2009). The effect of therapeutic zinc supplementation among young children with selected infections: a review of the evidence. Food Nutr. Bull. 30, S41-S59.

Hammer, N. D., and Skaar, E. P. (2012). The impact of metal sequestration on Staphylococcus aureus metabolism. Curr. Opin. Microbiol. 15, 10-14. doi: 10.1016/j.mib.2011.11.004

Hayden, J. A., Brophy, M. B., Cunden, L. S., and Nolan, E. M. (2013). Highaffinity manganese coordination by human calprotectin is calcium-dependent and requires the histidine-rich site formed at the dimer interface. J. Am. Chem. Soc. 135, 775-787. doi: 10.1021/ja3096416

Hendriksen, W. T., Bootsma, H. J., van Diepen, A., Estevão, S., Kuipers, O. P., de Groot, R., et al. (2009). Strain-specific impact of PsaR of Streptococcus pneumoniae on global gene expression and virulence. Microbiology 155, 1569-1579. doi: 10.1099/mic.0.025072-0

Hoffmann, O., Zweigner, J., Smith, S. H., Freyer, D., Mahrhofer, C., Dagand, E., et al. (2006). Interplay of pneumococcal hydrogen peroxide and host-derived nitric oxide. Infect. Immun. 74, 5058-5066. doi: 10.1128/IAI.01932-05

Hollenstein, K., Frei, D. C., and Locher, K. P. (2007). Structure of an ABC transporter in complex with its binding protein. Nature 446, 213-216. doi: 10.1016/ j.sbi.2007.07.003

Holmes, M. A., Paulsene, W., Jide, X., Ratledge, C., and Strong, R. K. (2005). Siderocalin ( $\operatorname{Lcn} 2$ ) also binds carboxymycobactins, potentially defending against mycobacterial infections through iron sequestration. Structure 13, 29-41. doi: 10.1016/j.str.2004.10.009

Hood, M. I., Mortensen, B. L., Moore, J. L., Zhang, Y., Kehl-Fie, T. E., Sugitani, N., et al. (2012). Identification of an Acinetobacter baumannii zinc acquisition system that facilitates resistance to calprotectin-mediated zinc sequestration. PLoS Pathog. 8:e1003068. doi: 10.1371/journal.ppat.1003068

Hood, M. I., and Skaar, E. P. (2012). Nutritional immunity: transition metals at the pathogen-host interface. Nat. Rev. Microbiol. 10, 525-537. doi: 10.1038/nrmicro2836

Hughes, H. V., Lisher, J. P., Hardy, G. G., Kysela, D. T., Arnold, R. J., Giedroc, D. P., et al. (2013). Coordinate synthesis and protein localization in a bacterial organelle by the action of a penicillin-binding-protein. Mol. Microbiol. doi: 10.1111/mmi.12422. [Epub ahead of print].

Imlay, J. A. (2008). Cellular defenses against superoxide and hydrogen peroxide. Annu. Rev. Biochem. 77, 755-776. doi: 10.1146/annurev.biochem.77.061606. 161055

Imlay, J. A. (2013). The molecular mechanisms and physiological consequences of oxidative stress: lessons from a model bacterium. Nat. Rev. Microbiol. 11, 443-454. doi: 10.1038/nrmicro3032
Inaoka, T., Matsumura, Y., and Tsuchido, T. (1999). SodA and manganese are essential for resistance to oxidative stress in growing and sporulating cells of Bacillus subtilis. J. Bacteriol. 181, 1939-1943.

Jacobsen, F. E., Kazmierczak, K. M., Lisher, J. P., Winkler, M. E., and Giedroc, D. P. (2011). Interplay between manganese and zinc homeostasis in the human pathogen Streptococcus pneumoniae. Metallomics 3, 38-41. doi: $10.1039 / \mathrm{c} 0 \mathrm{mt} 00050 \mathrm{~g}$

Jensen, L. T., Ajua-Alemanji, M., and Culotta, V. C. (2003). The Saccharomyces cerevisiae high affinity phosphate transporter encoded by PHO84 also functions in manganese homeostasis. J. Biol. Chem. 278, 42036-42040. doi: 10.1074/jbc. M307413200

Johnston, J. W., Briles, D. E., Myers, L. E., and Hollingshead, S. K. (2006). Mn2+dependent regulation of multiple genes in Streptococcus pneumoniae through PsaR and the resultant impact on virulence. Infect. Immun. 74, 1171-1180. doi: 10.1128/IAI.74.2.1171-1180.2006

Johnston, J. W., Myers, L. E., Ochs, M. M., Benjamin, W. H. Jr., Briles, D. E., and Hollingshead, S. K. (2004). Lipoprotein PsaA in virulence of Streptococcus pneumoniae: surface accessibility and role in protection from superoxide. Infect. Immun. 72, 5858-5867. doi: 10.1128/IAI.72.10.5858-5867.2004

Kaluarachchi, H., Chan Chung, K. C., and Zamble, D. B. (2010). Microbial nickel proteins. Nat. Prod. Rep. 27, 681-694. doi: 10.1039/b906688h

Karpowich, N. K., Huang, H. H., Smith, P. C., and Hunt, J. F. (2003). Crystal structures of the BtuF periplasmic-binding protein for vitamin B12 suggest a functionally important reduction in protein mobility upon ligand binding. J. Biol. Chem. 278, 8429-8434. doi: 10.1074/jbc.M212239200

Kehl-Fie, T. E., Chitayat, S., Hood, M. I., Damo, S., Restrepo, N., Garcia, C., et al. (2011). Nutrient metal sequestration by calprotectin inhibits bacterial superoxide defense, enhancing neutrophil killing of Staphylococcus aureus. Cell Host Microbe 10, 158-164. doi: 10.1016/j.chom.2011.07.004

Kehl-Fie, T. E., and Skaar, E. P. (2010). Nutritional immunity beyond iron: a role for manganese and zinc. Curr. Opin. Chem. Biol. 14, 218-224. doi: 10.1016/j.cbpa.2009.11.008

Kehl-Fie, T. E., Zhang, Y., Moore, J. L., Farrand, A. J., Hood, M. I., Rathi, S., et al. (2013). MntABC and MntH contribute to systemic Staphylococcus aureus infection by competing with calprotectin for nutrient manganese. Infect. Immun. 81, 3395-3405. doi: 10.1128/IAI.00420-13

Kehres, D. G., Zaharik, M. L., Finlay, B. B., and Maguire, M. E. (2000). The NRAMP proteins of Salmonella typhimurium and Escherichia coli are selective manganese transporters involved in the response to reactive oxygen. Mol. Microbiol. 36 , 1085-1100. doi: 10.1046/j.1365-2958.2000.01922.x

Kitamura, H., Morikawa, H., Kamon, H., Iguchi, M., Hojyo, S., Fukada, T., et al. (2006). Toll-like receptor-mediated regulation of zinc homeostasis influences dendritic cell function. Nat. Immunol. 7, 971-977. doi: 10.1038/ni1373

Kloosterman, T. G., Witwicki, R. M., van der Kooi-Pol, M. M., Bijlsma, J. J., and Kuipers, O. P. (2008). Opposite effects of Mn2+ and Zn2+ on PsaR-mediated expression of the virulence genes pcpA, prtA, and psaBCA of Streptococcus pneumoniae. J. Bacteriol. 190, 5382-5393. doi: 10.1128/JB.00307-08

Korkhov, V. M., Mireku, S. A., and Locher, K. P. (2012). Structure of AMP-PNPbound vitamin B12 transporter BtuCD-F. Nature 490, 367-372. doi: 10.1038/ nature 11442

Krishnamohan Sharma, C. V., Chusuei, C. C., Clérac, R., Möller, T., Dunbar, K. R., and Clearfield, A. (2003). Magnetic property studies of manganese-phosphate complexes. Inorg. Chem. 42, 8300-8308. doi: 10.1021/ic0300520

Kumar, V., and Choudhry, V. P. (2010). Iron deficiency and infection. Indian J. Pediatr. 77, 789-793. doi: 10.1007/s12098-010-0120-3

Lassi, Z. S., Haider, B. A., and Bhutta, Z. A. (2010). Zinc supplementation for the prevention of pneumonia in children aged 2 months to 59 months. Cochrane Database Syst. Rev. 12:CD005978. doi: 10.1002/14651858.CD005978.pub2

Lawrence, M. C., Pilling, P. A., Epa, V. C., Berry, A. M., Ogunniyi, A. D., and Paton, J. C. (1998). The crystal structure of pneumococcal surface antigen PsaA reveals a metal-binding site and a novel structure for a putative ABC-type binding protein. Structure 6, 1553-1561. doi: 10.1016/S0969-2126 (98)00153-1

Lee, J. W., and Helmann, J. D. (2006). The PerR transcription factor senses $\mathrm{H} 2 \mathrm{O} 2$ by metal-catalysed histidine oxidation. Nature 440, 363-367. doi: 10.1038/nature04537

Lee, Y. H., Deka, R. K., Norgard, M. V., Radolf, J. D., and Hasemann, C. A. (1999). Treponema pallidum TroA is a periplasmic zinc-binding protein with a helical backbone. Nat. Struct. Biol. 6, 628-633. doi: 10.1038/10677 
Lee, Y. H., Dorwart, M. R., Hazlett, K. R., Deka, R. K., Norgard, M. V., Radolf, J. D., et al. (2002). The crystal structure of $\mathrm{Zn}(\mathrm{II})$-free Treponema pallidum TroA, a periplasmic metal-binding protein, reveals a closed conformation. J. Bacteriol. 184, 2300-2304. doi: 10.1128/JB.184.8.2300-2304.2002

Li, H., and Jogl, G. (2007). Crystal structure of the zinc-binding transport protein ZnuA from Escherichia coli reveals an unexpected variation in metal coordination. J. Mol. Biol. 368, 1358-1366. doi: 10.1016/j.jmb.2007.02.107

Lieser, S. A., Davis, T. C., Helmann, J. D., and Cohen, S. M. (2003). DNAbinding and oligomerization studies of the manganese(II) metalloregulatory protein MntR from Bacillus subtilis. Biochemistry 42, 12634-12642. doi: 10.1021/bi0350248

Liochev, S. I., and Fridovich, I. (2004). Carbon dioxide mediates Mn(II)-catalyzed decomposition of hydrogen peroxide and peroxidation reactions. Proc. Natl. Acad. Sci. U.S.A. 101, 12485-12490. doi: 10.1073/pnas.0404911101

Lisher, J. P., Higgins, K. A., Maroney, M. J., and Giedroc, D. P. (2013). Physical Characterization of the Manganese-Sensing Pneumococcal Surface Antigen Repressor from Streptococcus pneumoniae. Biochemistry 52, 7689-7701. doi: 10.1021/bi401132w

Locher, K. P., Lee, A. T., and Rees, D. C. (2002). The, E. coli BtuCD structure: a framework for ABC transporter architecture and mechanism. Science 296, 1091-1098. doi: 10.1126/science. 1071142

Ma, Z., Faulkner, M. J., and Helmann, J. D. (2012). Origins of specificity and crosstalk in metal ion sensing by Bacillus subtilis Fur. Mol. Microbiol. 86, 1144-1155. doi: $10.1111 / \mathrm{mmi} .12049$

Ma, Z., Jacobsen, F. E., and Giedroc, D. P. (2009). Coordination chemistry of bacterial metal transport and sensing. Chem. Rev. 109, 4644-4681. doi: $10.1021 / \mathrm{cr} 900077 \mathrm{w}$

Ma, Z., Lee, J. W., and Helmann, J. D. (2011). Identification of altered function alleles that affect Bacillus subtilis PerR metal ion selectivity. Nucleic Acids Res. 39, 5036-5044. doi: 10.1093/nar/gkr095

Maret, W. (2001). Zinc biochemistry, physiology, and homeostasis-recent insights and current trends. Biometals 14, 187-190. doi: 10.1023/A:1012945110820

Maret, W. (2010). Metalloproteomics, metalloproteomes, and the annotation of metalloproteins. Metallomics 2, 117-125. doi: 10.1039/b915804a

May, B. P., and Dennis, P. P. (1989). Evolution and regulation of the gene encoding superoxide dismutase from the archaebacterium Halobacterium cutirubrum. J. Biol. Chem. 264, 12253-12258.

McDevitt, C. A., Ogunniyi, A. D., Valkov, E., Lawrence, M. C., Kobe, B., McEwan, A. G., et al. (2011). A molecular mechanism for bacterial susceptibility to zinc. PLoS Pathog. 7:e1002357. doi: 10.1371/journal.ppat.1002357

McNaughton, R. L., Reddi, A. R., Clement, M. H., Sharma, A., Barnese, K., Rosenfeld, L., et al. (2010). Probing in vivo Mn2+ speciation and oxidative stress resistance in yeast cells with electron-nuclear double resonance spectroscopy. Proc. Natl. Acad. Sci. U.S.A. 107, 15335-15339. doi: 10.1073/pnas. 1009648107

Moore, J. L., Becker, K. W., Nicklay, J. J., Boyd, K. L., Skaar, E. P., and Caprioli, R. M. (2013). Imaging mass spectrometry for assessing temporal proteomics: analysis of calprotectin in Acinetobacter baumannii pulmonary infection. Proteomics doi: 10.1002/pmic.201300046. [Epub ahead of print].

Ogunniyi, A. D., Mahdi, L. K., Jennings, M. P., McEwan, A. G., McDevitt, C. A., Van der Hoek, M. B., et al. (2010). Central role of manganese in regulation of stress responses, physiology, and metabolism in Streptococcus pneumoniae. J. Bacteriol. 192, 4489-4497. doi: 10.1128/JB.00064-10

Ong, C. L., Potter, A. J., Trappetti, C., Walker, M. J., Jennings, M. P., Paton, J. C., et al. (2013). Interplay between manganese and iron in pneumococcal pathogenesis: role of the orphan response regulator RitR. Infect. Immun. 81, 421-429. doi: 10.1128/IAI.00805-12

Osman, D., Waldron, K. J., Denton, H., Taylor, C. M., Grant, A. J., Mastroeni, P., et al. (2010). Copper homeostasis in Salmonella is atypical and copper-CueP is a major periplasmic metal complex. J. Biol. Chem. 285, 25259-25268. doi: 10.1074/jbc.M110.145953

Outten, C. E., and O'Halloran, T. V. (2001). Femtomolar sensitivity of metalloregulatory proteins controlling zinc homeostasis. Science 292, 2488-2492. doi: 10.1126/science.1060331

Papp-Wallace, K. M., and Maguire, M. E. (2006). Manganese transport and the role of manganese in virulence. Annu. Rev. Microbiol. 60, 187-209. doi: 10.1146/annurev.micro.60.080805.142149

Pericone, C. D., Park, S., Imlay, J. A., and Weiser, J. N. (2003). Factors contributing to hydrogen peroxide resistance in Streptococcus pneumoniae include pyruvate oxidase $(\mathrm{SpxB})$ and avoidance of the toxic effects of the fenton reaction. J. Bacteriol. 185, 6815-6825. doi: 10.1128/JB.185.23.6815-6825.2003

Perry, R. D., Craig, S. K., Abney, J., Bobrov, A. G., Kirillina, O., Mier, I., et al. (2012). Manganese transporters Yfe and $\mathrm{MntH}$ are Fur-regulated and important for the virulence of Yersinia pestis. Microbiology 158, 804-815. doi: 10.1099/mic.0.053710-0

Pinkett, H. W., Lee, A. T., Lum, P., Locher, K. P., and Rees, D. C. (2007). An inwardfacing conformation of a putative metal-chelate-type ABC transporter. Science 315, 373-377. doi: 10.1126/science.1133488

Plumptre, C. D., Ogunniyi, A. D., and Paton, J. C. (2012). Polyhistidine triad proteins of pathogenic streptococci. Trends Microbiol. 20, 485-493. doi: 10.1016/j.tim.2012.06.004

Plumptre, C. D., Ogunniyi, A. D., and Paton, J. C. (2013). Surface association of Pht proteins of Streptococcus pneumoniae. Infect. Immun. 81, 3644-3651. doi: 10.1128/IAI.00562-13

Posey, J. E., and Gherardini, F. C. (2000). Lack of a role for iron in the Lyme disease pathogen. Science 288, 1651-1653. doi: 10.1126/science.288.5471.1651

Potapov, A., and Goldfarb, D. (2008). The $\mathrm{Mn}(2+)$-bicarbonate complex in a frozen solution revisited by pulse W-band ENDOR. Inorg. Chem. 47, 10491-10498. doi: $10.1021 /$ ic 8011316

Raja, M. R., Waterman, S. R., Qiu, J., Bleher, R., Williamson, P. R., and O'Halloran, T. V. (2013). A copper hyperaccumulation phenotype correlates with pathogenesis in Cryptococcus neoformans. Metallomics 5, 363-371. doi: $10.1039 / \mathrm{c} 3 \mathrm{mt} 20220 \mathrm{~h}$

Ramos-Montañez, S., Kazmierczak, K. M., Hentchel, K. L., and Winkler, M. E. (2010). Instability of ackA (acetate kinase) mutations and their effects on acetyl phosphate and ATP amounts in Streptococcus pneumoniae D39. J. Bacteriol. 192, 6390-6400. doi: 10.1128/JB.00995-10

Reddi, A. R., and Culotta, V. C. (2011). Regulation of manganese antioxidants by nutrient sensing pathways in Saccharomyces cerevisiae. Genetics 189, 1261-1270. doi: 10.1534/genetics.111.134007

Reyes-Caballero, H., Campanello, G. C., and Giedroc, D. P. (2011). Metalloregulatory proteins: metal selectivity and allosteric switching. Biophys. Chem. 156, 103-114. doi: 10.1016/j.bpc.2011.03.010

Reyes-Caballero, H., Guerra, A. J., Jacobsen, F. E., Kazmierczak, K. M., Cowart, D., Koppolu, U. M., et al. (2010). The metalloregulatory zinc site in Streptococcus pneumoniae AdcR, a zinc-activated MarR family repressor. J. Mol. Biol. 403, 197-216. doi: 10.1016/j.jmb.2010.08.030

Riboldi-Tunnicliffe, A., Isaacs, N. W., and Mitchell, T. J. (2005). 1.2 Angstroms crystal structure of the S. pneumoniae PhtA histidine triad domain a novel zinc binding fold. FEBS Lett. 579, 5353-5360. doi: 10.1016/j.febslet. 2005.08.066

Rivera-Mancía, S., Ríos, C., and Montes, S. (2011). Manganese accumulation in the CNS and associated pathologies. Biometals 24, 811-825. doi: 10.1007/s10534011-9454-1

Rolerson, E., Swick, A., Newlon, L., Palmer, C., Pan, Y., Keeshan, B., et al. (2006). The SloR/Dlg metalloregulator modulates Streptococcus mutans virulence gene expression. J. Bacteriol. 188, 5033-5044. doi: 10.1128/JB.00155-06

Rosch, J. W., Gao, G., Ridout, G., Wang, Y. D., and Tuomanen, E. I. (2009). Role of the manganese efflux system mntE for signalling and pathogenesis in Streptococcus pneumoniae. Mol. Microbiol. 72, 12-25. doi: 10.1111/j.13652958.2009.06638.x

Rosenfeld, L., and Culotta, V. C. (2012). Phosphate disruption and metal toxicity in Saccharomyces cerevisiae: effects of RAD23 and the histone chaperone HPC2. Biochem. Biophys. Res. Commun. 418, 414-419. doi: 10.1016/j.bbrc. 2012.01.047

Rosenfeld, L., Reddi, A. R., Leung, E., Aranda, K., Jensen, L. T., and Culotta, V. C. (2010). The effect of phosphate accumulation on metal ion homeostasis in Saccharomyces cerevisiae. J. Biol. Inorg. Chem. 15, 1051-1062. doi: 10.1007/s00775-010-0664-8

Rowland, J. L., and Niederweis, M. (2012). Resistance mechanisms of Mycobacterium tuberculosis against phagosomal copper overload. Tuberculosis 92, 202-210. doi: 10.1016/j.tube.2011.12.006

Rukhman, V., Anati, R., Melamed-Frank, M., and Adir, N. (2005). The MntC crystal structure suggests that import of $\mathrm{Mn} 2+$ in cyanobacteria is redox controlled. J. Mol. Biol. 348, 961-969. doi: 10.1016/j.jmb.2005.03.006

Samanovic, M. I., Ding, C., Thiele, D. J., and Darwin, K. H. (2012). Copper in microbial pathogenesis: meddling with the metal. Cell Host Microbe 11, 106-115. doi: 10.1016/j.chom.2012.01.009 
Shafeeq, S., Kloosterman, T. G., and Kuipers, O. P. (2011). Transcriptional response of Streptococcus pneumoniae to $\mathrm{Zn} 2+$ limitation and the repressor/activator function of AdcR. Metallomics 3, 609-618. doi: 10.1039/c1mt00030f

Shafeeq, S., Kuipers, O. P., and Kloosterman, T. G. (2013). The role of zinc in the interplay between pathogenic streptococci and their hosts. Mol. Microbiol. 88, 1047-1057. doi: 10.1111/mmi.12256

Sharma, A., Gaidamakova, E. K., Matrosova, V. Y., Bennett, B., Daly, M. J., and Hoffman, B. M. (2013). Responses of Mn2+ speciation in Deinococcus radiodurans and Escherichia coli to gamma-radiation by advanced paramagnetic resonance methods. Proc. Natl. Acad. Sci. U.S.A. 110, 5945-5950. doi: 10.1073/pnas. 1303376110

Sia, A. K., Allred, B. E., and Raymond, K. N. (2013). Siderocalins: siderophore binding proteins evolved for primary pathogen host defense. Curr. Opin. Chem. Biol. 17, 150-157. doi: 10.1016/j.cbpa.2012.11.014

Skaar, E. P. (2010). The battle for iron between bacterial pathogens and their vertebrate hosts. PLoS Pathog. 6:e1000949. doi: 10.1371/journal.ppat.1000949

Skamene, E., Gros, P., Forget, A., Kongshavn, P. A., St Charles, C., and Taylor, B. A (1982). Genetic regulation of resistance to intracellular pathogens. Nature 297, 506-509. doi: 10.1038/297506a0

Sobota, J. M., and Imlay, J. A. (2011). Iron enzyme ribulose-5-phosphate 3epimerase in Escherichia coli is rapidly damaged by hydrogen peroxide but can be protected by manganese. Proc. Natl. Acad. Sci. U.S.A. 108, 5402-5407. doi: 10.1073/pnas.1100410108

Stadtman, E. R., Berlett, B. S., and Chock, P. B. (1990). Manganese-dependent disproportionation of hydrogen peroxide in bicarbonate buffer. Proc. Natl. Acad. Sci. U.S.A. 87, 384-388. doi: 10.1073/pnas.87.1.384

Stafford, S. L., Bokil, N. J., Achard, M. E., Kapetanovic, R., Schembri, M. A., McEwan, A. G., et al. (2013). Metal ions in macrophage antimicrobial pathways: emerging roles for zinc and copper. Biosci. Rep. 33, art:e00049. doi: 10.1042/BSR20130014

Stern, A. M., Liu, B., Bakken, L. R., Shapleigh, J. P., and Zhu, J. (2013). A novel protein protects bacterial iron-dependent metabolism from nitric oxide. J. Bacteriol. 195, 4702-4708. doi: 10.1128/JB.00836-13

Tottey, S., Waldron, K. J., Firbank, S. J., Reale, B., Bessant, C., Sato, K., et al. (2008). Protein-folding location can regulate manganese-binding versus copper- or zinc-binding. Nature 455, 1138-1142. doi: 10.1038/nature07340

Tseng, H. J., Srikhanta, Y., McEwan, A. G., and Jennings, M. P. (2001). Accumulation of manganese in Neisseria gonorrhoeae correlates with resistance to oxidative killing by superoxide anion and is independent of superoxide dismutase activity. Mol. Microbiol. 40, 1175-1186. doi: 10.1046/j.13652958.2001.02460.x

Versieck, J. (1985). Trace elements in human body fluids and tissues. Crit. Rev. Clin. Lab. Sci. 22, 97-184. doi: 10.3109/10408368509165788

Veyrier, F. J., Boneca, I. G., Cellier, M. F., and Taha, M. K. (2011). A novel metal transporter mediating manganese export $(\mathrm{MntX})$ regulates the $\mathrm{Mn}$ to Fe intracellular ratio and Neisseria meningitidis virulence. PLoS Pathog. 7:e1002261. doi: 10.1371/journal.ppat.1002261

Wagner, D., Maser, J., Lai, B., Cai, Z., Barry, C. E., 3rd, Höner Zu Bentrup, K., et al. (2005). Elemental analysis of Mycobacterium avium-, Mycobacterium tuberculosis-, and Mycobacterium smegmatis-containing phagosomes indicates pathogen-induced microenvironments within the host cell's endosomal system. J. Immunol. 174, 1491-1500.

Waldron, K. J., and Robinson, N. J. (2009). How do bacterial cells ensure that metalloproteins get the correct metal. Nat. Rev. Microbiol. 7, 25-35. doi: $10.1038 /$ nrmicro2057
Waldron, K. J., Rutherford, J. C., Ford, D., and Robinson, N. J. (2009). Metalloproteins and metal sensing. Nature 460, 823-830. doi: 10.1038/ nature 08300

Weinberg, E. D. (1974). Iron and susceptibility to infectious disease. Science 184, 952-956. doi: 10.1126/science.184.4140.952

Weinberg, E. D. (1975). Nutritional immunity. Host's attempt to withold iron from microbial invaders. JAMA 231, 39-41. doi: 10.1001/jama.1975.03240130021018

Whaley, M. J., Sampson, J. S., Johnson, S. E., Rajam, G., Stinson-Parks, A., Holder, P., et al. (2010). Concomitant administration of recombinant PsaA and PCV7 reduces Streptococcus pneumoniae serotype 19A colonization in a murine model. Vaccine 28, 3071-3075. doi: 10.1016/j.vaccine.2010. 02.086

White, C., Lee, J., Kambe, T., Fritsche, K., and Petris, M. J. (2009). A role for the ATP7A copper-transporting ATPase in macrophage bactericidal activity. J. Biol. Chem. 284, 33949-33956. doi: 10.1074/jbc.M109.070201

Whittaker, J. W. (2003). The irony of manganese superoxide dismutase. Biochem. Soc. Trans. 31, 1318-1321. doi: 10.1042/BST0311318

Whittaker, J. W. (2012). Non-heme manganese catalase-the 'other' catalase. Arch. Biochem. Biophys. 525, 111-120. doi: 10.1016/j.abb.2011.12.008

Wichgers Schreur, P. J., Rebel, J. M., Smits, M. A., van Putten, J. P., and Smith, H. E. (2011). TroA of Streptococcus suis is required for manganese acquisition and full virulence. J. Bacteriol. 193, 5073-5080. doi: 10.1128/JB.05305-11

Wintjens, R., Noël, C., May, A. C., Gerbod, D., Dufernez, F., Capron, M., et al. (2004). Specificity and phenetic relationships of iron- and manganese-containing superoxide dismutases on the basis of structure and sequence comparisons. J. Biol. Chem. 279, 9248-9254. doi: 10.1074/jbc.M312 329200

Wu, H. J., Seib, K. L., Srikhanta, Y. N., Edwards, J., Kidd, S. P., Maguire, T. L., et al. (2010). Manganese regulation of virulence factors and oxidative stress resistance in Neisseria gonorrhoeae. J. Proteomics 73, 899-916. doi: 10.1016/j.jprot.2009.12.001

Zheng, B., Zhang, Q., Gao, J., Han, H., Li, M., Zhang, J., et al. (2011). Insight into the interaction of metal ions with TroA from Streptococcus suis. PLoS ONE 6:e19510. doi: 10.1371/journal.pone.0019510

Zheng, M., Wang, X., Doan, B., Lewis, K. A., Schneider, T. D., and Storz, G. (2001). Computation-directed identification of OxyR DNA binding sites in Escherichia coli. J. Bacteriol. 183, 4571-4579. doi: 10.1128/JB.183.15.4571-4579.2001

Conflict of Interest Statement: The authors declare that the research was conducted in the absence of any commercial or financial relationships that could be construed as a potential conflict of interest.

Received: 01 October 2013; paper pending published: 17 October 2013; accepted: 18 November 2013; published online: 05 December 2013.

Citation: Lisher JP and Giedroc DP (2013) Manganese acquisition and homeostasis at the host-pathogen interface. Front. Cell. Infect. Microbiol. 3:91. doi: 10.3389/fcimb. 2013.00091

This article was submitted to the journal Frontiers in Cellular and Infection Microbiology.

Copyright (c) 2013 Lisher and Giedroc. This is an open-access article distributed under the terms of the Creative Commons Attribution License (CC BY). The use, distribution or reproduction in other forums is permitted, provided the original author(s) or licensor are credited and that the original publication in this journal is cited, in accordance with accepted academic practice. No use, distribution or reproduction is permitted which does not comply with these terms. 